\title{
Unrecognized Taphonomy as a Problem of Identification and the Scale of Contamination of Archaeobotanical Assemblages - the Example of Prague - Zličín Migration Period Burial Ground
}

\author{
Tereza Šálkováa,b,f* , Alena Dohnalovác ${ }^{\text {J Jan Novák }}{ }^{\mathrm{b}}$, Tomáš Hiltscher ${ }^{\mathrm{d}}$, Jaroslav Jiřík ${ }^{\mathrm{d}, \mathrm{e}}$, Jiří Vávra $^{\mathrm{f}}$ \\ ${ }^{a}$ University of South Bohemia, Faculty of Philosophy, Institute of Archaeology, Branišovská 31a, 37005 České Budějovice, Czech Republic \\ ${ }^{b}$ University of South Bohemia, Faculty of Science, Na Zlaté stoce 3, Laboratory of Archaeobotany and Palaeoecology, 37005 České Budějovice, Czech Republic \\ 'Masaryk University, Faculty of Science, Department of Geological Sciences, Kotlářská 2, 61137 Brno, Czech Republic \\ 'Prácheň Museum in Písek, Velké náměsti 114, 39724 Pisek, Czech Republic \\ ${ }^{e}$ Charles University in Prague, Faculty of Arts, Institute of Prehistory and Early History, Celetná 20, 11636 Praha 1, Czech Republic \\ fLabrys, o. p. s., Hloubětinská 16/11, 198 00, Praha 9 - Hloubětín, Czech Republic
}

\section{A RTICLE INFO}

\section{Article history:}

Received: $7^{\text {th }}$ December 2015

Accepted: $28^{\text {th }}$ November 2016

\section{Key words:}

archaeobotany

contamination

plant macroremains

wood

charcoal

pollen

graves

Migration Period

\begin{abstract}
$A B S T R A C T$
This research aimed to compare different sources of botanical material obtained from the infill of Migration Period graves (Vinařice group, $5^{\text {th }}$ century and the turn of $5^{\text {th }}$ and $6^{\text {th }}$ century AD) in Prague Zličín during 2005-2008. From a total number of 173 excavated graves with 176 burials, 74 were sampled for archaeobotanical analyses, and these are the subject of this contribution. All of the researched graves were robbed shortly after the time of burial. The archaeobotanical approach was applied through three methods: macroremains analysis; anthracology - xylotomy; and pollen analysis. The samples had low densities of plant macroremains, and contained many residuals and contaminants which had penetrated the graves' infill. Only a fragment of the pollen samples was positive. Knowledge about the penetration of intact features by earlier and later plant remains was of major importance in the development of the methodology used for this research in the graves.
\end{abstract}

\section{Introduction}

The role of plants in the burial rites of different societies can be studied through analyses of their remains recovered from grave deposits (Hansson, Bergström 2002). However, the problems of intrusion and residuality in archaeobotany are most acute in periods in which plant assemblages are generally less abundant than in others (Pelling et al. 2015). For example, a low density of carbonized and mineralized macroremains (with contaminants) has been demonstrated in open settlement sites with a long history of human occupation, cultivation, grazing, and bioturbation. The spectra of macroremains found there are often, at least partially, "mixed" or contaminated due to depositional and post-depositional processes (Borojevic 2011).
By studying an assemblage of plant remains from partially wet sediments in the Migration Period graves at Prague Zličín (Jiř́k et al. 2015), we have shown that the same can also be true for burial sites situated in an area with a history of long-term occupation. The archaeobotany of Migration Period burial grounds in central Europe is very rare (e.g. Hopf 1979; Theune-Großkopf 2010), and our research at the large burial ground in Prague Zličín is therefore unique. Rigorous sampling of excavated sediments has been applied (Figure 1), and three types of archaeobotanical materials studied: plant diaspores, charred and uncharred wood, and pollen with non-pollen polymorphs.

The aim of this research is to:

- determine the relationship between various types of plant remains, and their positions in graves (e.g. coffin, looting shaft, various layers of the infill);

- reconstruct the process of plant intrusion and residuality at the site; 


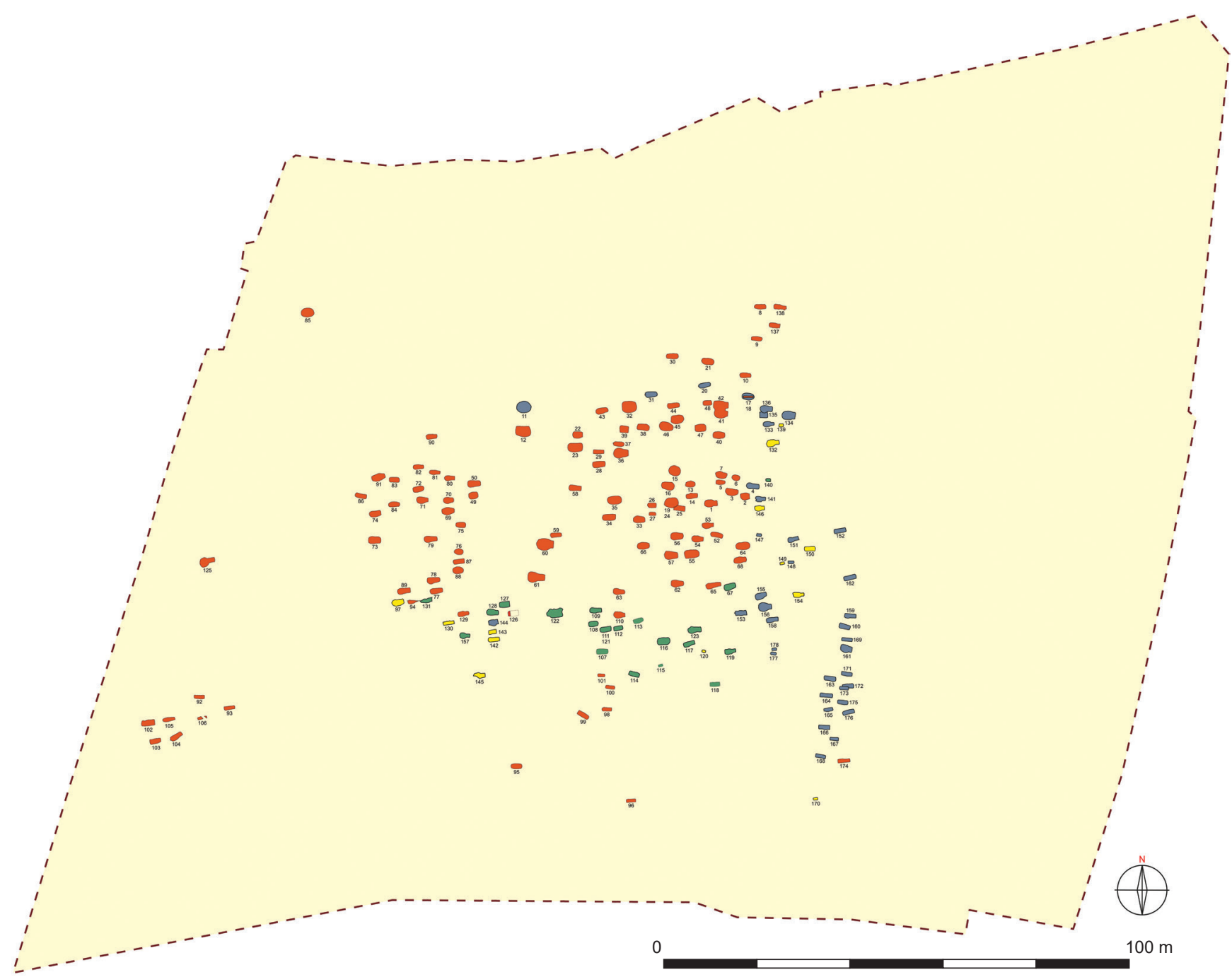

Figure 1. Prague Zličín; plan of the excavation. Blue - graves with floated samples, green - graves with pollen analysis, yellow - graves with both floated samples and pollen analysis.

- reconstruct the burial rite, with a focus on the role of plants;

- reconstruct the vegetation of the area during the "life" of the burial ground.

\section{Background information about the site}

Rescue excavations in Prague Zličín (2005-2008) uncovered a multi-period site with a number of settlement features from farming pre- and protohistory, and 176 burials in 173 graves - dated to the $5^{\text {th }}$ century AD and the turn of the $5^{\text {th }}$ and $6^{\text {th }}$ century - belonging to the Migration Period Vinařice group (Vávra et al. 2012, 3, Figure 2). The burial ground represents the largest inhumation cemetery from the early phase of the Migration Period excavated in Bohemia up to now (Svoboda 1965, especially list of grave yards at pp. 237-295), and it is also one of the largest cemeteries in central Europe (Figure 1). The assemblage of the grave goods from the Prague Zličín graves reflects a material culture from the greater part of the $5^{\text {th }}$ century, a dating which is also supported by radiocarbon dates on human skeletal material. The wide spectrum of the finds demonstrates extensive contacts with various parts of the Barbaricum, as well as the (former) Roman provinces (i.e. "barbarian kingdoms" on Roman territory). Within the relative chronology, the dating of the site can be attributed to the phases D2-D3/E1 sensu J. Tejral (Vávra et al. 2012, 1-3). Accordingly, it was hoped that the site would offer a unique set of information about burial processes and the life of the inhabitants of the Bohemian Basin during the Migration Period.

Settlement features from other than the Migration Period, located among the graves (Vávra et al. 2012, Figure 2), can be attributed to the Bronze Age and/or to a wide category of "farming prehistory". The artefacts recovered from all depths of the features of the Migration Period graves date the occupation of the site more closely. They point to the use of the area during the Neolithic, Late Neolithic, Late Bronze Age and La Tène Period (Vávra, Kuchařík 2015, 123). Occupation of the area from the Late Iron Age to the Early 
Roman Period could be attested by a fragment of animal bone from grave no. 142 dated by AMS (see results).

It is very important to stress that almost all of the graves in Prague Zličín had been reopened and robbed in ancient times, as is often the case (Vávra, Kuchařík 2015, 130-147). There is factual uncertainty about the filling mechanism used for the looting shafts. This probably differed in each case. Assumptions as to the filling of the shafts can only be made in connection with the physical evidence at the site. This is due to the fact that the depths of the graves are variable (see above), and if left open (which seems more probable-given the humous character of the infill, which is clearly different in comparison to the backfill of the grave itself-than the possibility that the looters found the time to refill the open grave) then the time necessary for the shaft to be filled would differ according to the individual extent of the secondary intervention, and also perhaps the slope of the terrain. Without radiocarbon dating of specially-selected plant macroremains, which would indicate contamination by earlier residua as well as later intrusions, interpretation of the assemblage of plant remains is virtually impossible.

Regardless of these circumstances, the material from Prague Zličín represents an important body of data on the plant use and vegetation in different time periods, as well as information about coffin manufacture, possible looting equipment directly connected to the robbing of these graves, and the dating of these events (see Vávra et al. 2012, 3, 10-13, Table 1).

The graves, varying in depth $(0.12-2.6 \mathrm{~m})$, disposition and presence of grave goods, provided variable chemical conditions for the preservation of their organic material. The analyses of the archaeological finds from the graves revealed a wide range of organic, usually perishable, finds in several dozens of cases. Apart from the bones of the deceased, they included bone or antler artefacts (e.g. grave no. 54, 113), hair/ fur/scalp (grave no. 11), leather (e.g. graves no. 132, 152), textile or its imprint (e.g. grave no. 143 and 172), fragments of wooden handles of knives, and an arrow shaft. All of these finds were preserved due to the increased humidity of the sediment (wet, but not waterlogged), or by metal corrosion products (e.g. oxides and sulphides of copper), if connected to the metal finds. The first group, preserved due to the higher soil moisture, included non-carbonized wood (interpreted as remains of the coffins, grave goods such as wooden dishes or furniture, and tools-like hoes, shovels and torches-used for looting). A similar scale of artefacts was reported, for example, from the unique grave-chamber of Poprad-Matejovce, dated to the late $4^{\text {th }} /$ early $5^{\text {th }}$ century AD (Lau, Pieta 2014), where the exceptionally good preservation of the grave chamber was possible due to the waterlogged conditions. In the second group, carbonized diaspores and wood which was connected with the use of fire in the area of the burial ground, or in its hinterland, at the time of human activities at the site, were found. A direct connection between the burial rite and the remains of carbonized plants was impossible without a radiocarbon dating of all finds.

\section{Material and methods}

\subsection{Material}

The evaluated assemblage is comprised of various types of plant remains obtained from two main types of contexts: funerary and settlement deposits of different age. Macroremains are represented by seeds of cultivated and wild plants, cereal chaff, leaves of conifers, etc., and fragments of wood, preserved in charred, waterlogged, and mineralised form. Pollen grains represent the microremains.

\subsubsection{Graves}

Plant macroremains were recovered from sediment samples collected at different parts of the infill of the various graves: all together 614 samples from 53 graves. Samples were taken to obtain both botanical macroremains and small artefacts. Due to the low density of plant remains per sample, and for better evaluation and interpretation of results, they were divided into 5 groups. These groups are: infill of the coffins and/or the bottom parts of graves (R); upper infill of the graves (J); plunderers' shafts (S); and "transitional" or uncertain contexts of unknown or mixed depth within upper grave infill or plunderers' shafts (JS); and, coffins or plunderers' shafts (RS; Table 2; Figure 2). In three graves (nos. 9, 11, 12), larger remains of wooden coffins were documented in situ.

From cleaned surfaces of the profiles of the 34 graves, 95 samples were placed in small boxes and analysed for pollen (Table 1).

Figure 2. Prague Zličín; model grave with base contexts. ( $\mathrm{R}$ and blue - coffins, $\mathrm{J}$ and green - graves infill, $\mathrm{S}$ and orange - looting shafts, RS and JS - borders between coffin looting shaft or between coffin/grave infill).

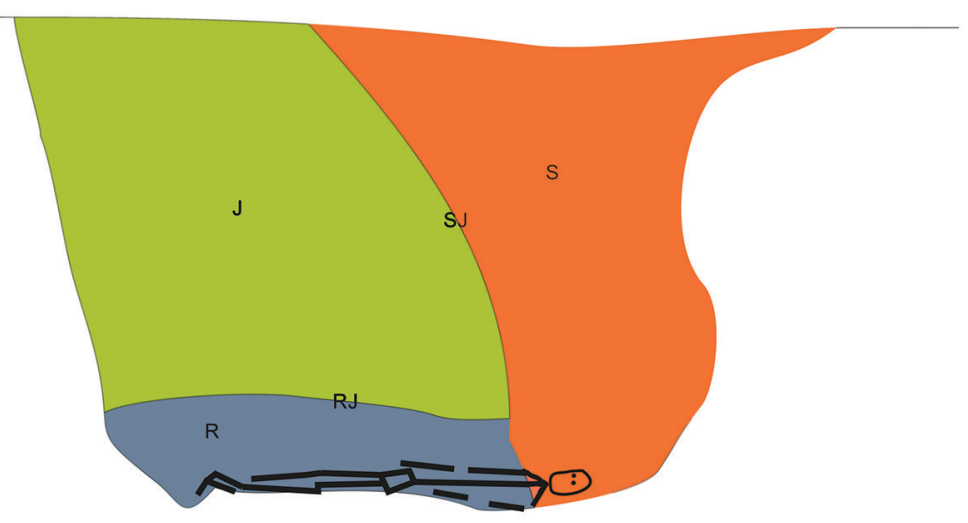


Table 1. Prague Zličín; list of graves with samples analysed by method of macroremains analysis, charcoal/wood analysis and pollen analysis. (In parentheses is the number of pollen samples with more than 100 determinations).

\begin{tabular}{|c|c|c|c|c|c|c|}
\hline Grave number & $\begin{array}{c}\begin{array}{c}\text { Samples volume } \\
\text { (flotation) }\end{array} \\
\end{array}$ & $\begin{array}{l}\text { Macroremains } \\
\text { samples count }\end{array}$ & $\begin{array}{l}\text { Charcoal/wood } \\
\text { samples count }\end{array}$ & $\begin{array}{c}\text { Pollen sample } \\
\text { count }\end{array}$ & $\begin{array}{l}\text { Positive pollen } \\
\text { samples count }\end{array}$ & $\begin{array}{c}\begin{array}{c}\text { Negative pollen } \\
\text { samples count }\end{array} \\
\end{array}$ \\
\hline 4 & 180 & 6 & 1 & & & \\
\hline 11 & 150 & 6 & 4 & & & \\
\hline 17 & 1 & 1 & 1 & & & \\
\hline 20 & 1 & 1 & 1 & & & \\
\hline 31 & 30 & 1 & 1 & & & \\
\hline 67 & & & & 3 & 1 & 2 \\
\hline 97 & 30 & 1 & 1 & 2 & & 2 \\
\hline 107 & & & & 8 & & 8 \\
\hline 108 & & & & 5 & 1 & 4 \\
\hline 109 & & & & 5 & 2 & 3 \\
\hline 112 & & & & 3 & 2 & 1 \\
\hline 113 & & & & 3 & & 3 \\
\hline 114 & & & & 4 & 3 & 1 \\
\hline 115 & & & & 2 & & 2 \\
\hline 116 & & & & 1 & 1 & \\
\hline 117 & & & & 5 & 2 & 3 \\
\hline 118 & & & & 1 & & 1 \\
\hline 119 & & & & 5 & 2 & 3 \\
\hline 120 & 1 & 1 & & 1 & $1(1)$ & \\
\hline 121 & & & & 3 & 2 & 1 \\
\hline 122 & & & & 4 & 1 & 3 \\
\hline 123 & & & & 6 & $3(2)$ & 3 \\
\hline 124 & & & & 1 & & 1 \\
\hline 127 & & & & 3 & 1 & 2 \\
\hline 128 & & & & 3 & 2 & 1 \\
\hline 130 & 30 & 1 & 1 & 3 & 2 & 1 \\
\hline 131 & & & & 2 & 1 & 1 \\
\hline 132 & 800 & 29 & 13 & 1 & & 1 \\
\hline 133 & 335 & 13 & 3 & & & \\
\hline 134 & 390 & 17 & 4 & & & \\
\hline 135 & 270 & 10 & 3 & & & \\
\hline 136 & 1,118 & 35 & 18 & & & \\
\hline 137 & 155 & 6 & 2 & & & \\
\hline 138 & 395 & 12 & 5 & & & \\
\hline 139 & 30 & 1 & & 1 & & 1 \\
\hline 140 & & & & 7 & 1 & 6 \\
\hline 141 & 925 & 35 & 15 & & & \\
\hline 142 & 8 & 2 & & 1 & & 1 \\
\hline 143 & 445 & 15 & 15 & 1 & & 1 \\
\hline 144 & 125 & 4 & 2 & & & \\
\hline 145 & 35 & 4 & 1 & 2 & 2 & \\
\hline 146 & 490 & 16 & 5 & 1 & & 1 \\
\hline 147 & 55 & 2 & 2 & & & \\
\hline 148 & 370 & 12 & 2 & & & \\
\hline 149 & 370 & 10 & 5 & 2 & & 2 \\
\hline 150 & 304 & 15 & 10 & 1 & & 1 \\
\hline 151 & 362 & 14 & 5 & & & \\
\hline 152 & 175 & 11 & 3 & & & \\
\hline 153 & 490 & 19 & 10 & & & \\
\hline 154 & 285 & 10 & 3 & 2 & $2(1)$ & \\
\hline 155 & 360 & 11 & 6 & & & \\
\hline 156 & 450 & 15 & 4 & & & \\
\hline
\end{tabular}


Table 1. Prague Zličín; list of graves with samples analysed by method of macroremains analysis, charcoal/wood analysis and pollen analysis. (In parentheses is the number of pollen samples with more than 100 determinations). (Continuation)

\begin{tabular}{|c|c|c|c|c|c|c|}
\hline Grave number & $\begin{array}{c}\text { Samples volume } \\
\text { (flotation) }\end{array}$ & $\begin{array}{l}\text { Macroremains } \\
\text { samples count }\end{array}$ & $\begin{array}{l}\text { Charcoal/wood } \\
\text { samples count }\end{array}$ & $\begin{array}{c}\text { Pollen sample } \\
\text { count }\end{array}$ & $\begin{array}{l}\text { Positive pollen } \\
\text { samples count }\end{array}$ & $\begin{array}{c}\text { Negative pollen } \\
\text { samples count }\end{array}$ \\
\hline 157 & & & & 2 & 1 & 1 \\
\hline 158 & 300 & 9 & 1 & & & \\
\hline 159 & 387 & 19 & 14 & & & \\
\hline 160 & 390 & 15 & 2 & & & \\
\hline 161 & 323 & 13 & 2 & & & \\
\hline 162 & 330 & 22 & 8 & & & \\
\hline 163 & 516 & 19 & 5 & & & \\
\hline 164 & 799 & 32 & 15 & & & \\
\hline 165 & 190 & 7 & & & & \\
\hline 166 & 331 & 17 & 4 & & & \\
\hline 167 & 173 & 10 & 5 & & & \\
\hline 168 & 180 & 13 & 6 & & & \\
\hline 169 & 97 & 5 & 2 & & & \\
\hline 170 & 110 & 4 & 2 & 1 & & 1 \\
\hline 171 & 416 & 22 & 15 & & & \\
\hline 172 & 395 & 20 & 3 & & & \\
\hline 173 & 163 & 7 & 6 & & & \\
\hline 174 & 245 & 8 & 3 & & & \\
\hline 175 & 294 & 15 & 6 & & & \\
\hline 176 & 377 & 16 & 4 & & & \\
\hline 177 & 140 & 4 & 2 & & & \\
\hline 178 & 30 & 1 & 1 & & & \\
\hline 74 graves & 15,351 litre & $\begin{array}{c}53 \text { graves/ } \\
614 \text { sampels }\end{array}$ & $\begin{array}{c}49 \text { graves/ } \\
252 \text { sampels }\end{array}$ & $\begin{array}{l}34 \text { graves/ } \\
95 \text { samples }\end{array}$ & $\begin{array}{l}25 \text { graves/ } \\
33 \text { samples }\end{array}$ & $\begin{array}{l}30 \text { graves/ } \\
62 \text { samples }\end{array}$ \\
\hline
\end{tabular}

Table 2. Prague Zličín; list of individual types of contexts and their properties (number of samples and their volume, number of carbonized, non-carbonized/ waterlogged macroremains and their concentration - average number per litre of sediment).

\begin{tabular}{|c|c|c|c|c|c|c|}
\hline & $\begin{array}{l}\text { Number of } \\
\text { samples }\end{array}$ & $\begin{array}{l}\text { Sediment } \\
\text { volume (l) }\end{array}$ & Carbonized & $\begin{array}{l}\text { Noncarbonized/ } \\
\text { waterlogged }\end{array}$ & $\begin{array}{r}\text { Carbonized } \\
\text { concentration }\end{array}$ & $\begin{array}{l}\text { Noncarbonized/ } \\
\text { waterlogged } \\
\text { concentration }\end{array}$ \\
\hline coffins and bottom of graves $(\mathrm{R})$ & 187 & 4,181 & 102 & 548 & 0.024 & 0.131 \\
\hline graves backfilling $(\mathrm{J})$ & 96 & 2,771 & 111 & 481 & 0.039 & 0.169 \\
\hline plundering shaft (S) & 201 & 5,105 & 67 & 398 & 0.024 & 0.144 \\
\hline $\begin{array}{l}\text { coffins and bottom of graves/ } \\
\text { plundering shaft (RS) }\end{array}$ & 114 & 2,841 & 133 & 888 & 0.026 & 0.174 \\
\hline $\begin{array}{l}\text { graves backfilling/ plundring } \\
\text { shaft (JS) }\end{array}$ & 15 & 426 & 20 & 125 & 0.047 & 0.293 \\
\hline roads $(\mathrm{C})$ & 9 & 150 & 0 & 7 & 0.000 & 0.047 \\
\hline other features (X) & 22 & 569 & 24 & 589 & 0.042 & 1.035 \\
\hline summary & 644 samples & 16,043 litre & 457 & 3036 & 0.029 & 0.285 \\
\hline
\end{tabular}

\subsubsection{Settlement features}

An assemblage of 31 samples was also collected and analysed from other than funerary deposits. Of these, 22 samples came from settlement features, and nine from excavated remnants of a road (the "trackway"). Ten samples were studied by anthracology and xylotomy: two samples from the road, and eight samples from settlement features. Roads (features 816, 1588 and 1553; in Tables and Figures marked as C) were filled by humid soils before the cemetery was founded in the $5^{\text {th }}$ century $\mathrm{AD}$, and evaluated overall.
The road was dated to "agricultural prehistory", but feature no. 816 was of an earlier date than the excavated graves, indicated by its superposition relative to three of them. One settlement feature (no. 1542) was dated based on ceramic typology to the Late Bronze Age; other features (nos. 1584, 1606, 1607 and 1608; in Tables and Figures marked as X) were dated based on material culture only as "agricultural prehistory" (Table 2). Three samples were obtained from settlement features numbers 794 and 813 and analysed by pollen analysis methods. 


\subsection{Methods}

Plant macroremains and wood and charcoal fragments were extracted from archaeological sediments by water flotation. A flotation tank (modified ANAKARA type; Pearsall 1989) was used for flotation at the time of excavation (573 samples, 15,303 litres; 21 samples of visible plant remains were handpicked directly during excavation). The manual technique of flotation was used in the laboratory for extraction of samples from the close proximity of bones and artefacts (48 samples, 48 litres). The light fraction was collected on sieves with mesh sizes of $0.25,0.4,1.0,2.0 \mathrm{~mm}$, and mineral residuum on the mesh of $1 \mathrm{~mm}$. Both float and heavy fractions were sorted in full, and analysed under a stereomicroscope. Determination of all plant macroremains is based on a wide range of standard literature, e.g. Berggren (1981); Anderberg (1994); Cappers et al. $(2006 ; 2009)$ and a comparative seed collection. In this analysis, NISP (Number of Identified Specimens) was used as the primary method of quantification.

Analysis of charcoals and wood was performed only on fragments from the large fraction $(>2 \mathrm{~mm})$ and only randomly selected samples were analysed. Smaller charcoal pieces, that were not taxonomically identifiable, were excluded because they seldom provide useful palaeoecological information (e.g. Robin et al. 2014). Charcoal and waterlogged wood were analysed with the use of an episcopic interference microscope with 200-500× magnification. Identification

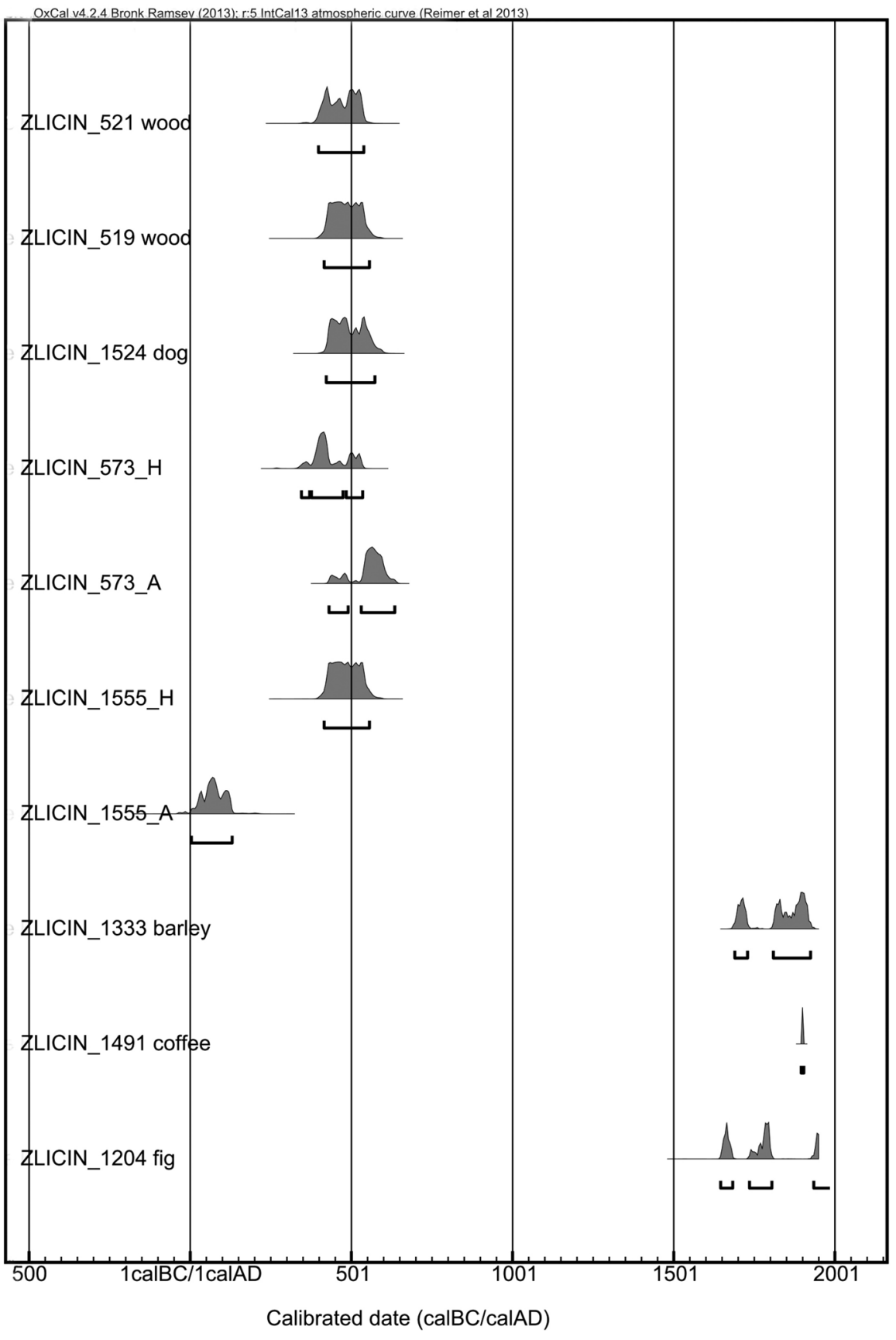

Figure 3. Prague Zličín; AMS radiocarbon dating. Calibration: $\mathrm{H}$ - human bones, $\mathrm{A}-$ animal bones. Calibration 95.4\% (Bronk Ramsey 2013, Reimer et al. 2013). 
Table 3. Prague Zličín; AMS radiocarbon data.

\begin{tabular}{cccccc}
\hline Sample & Lab. code & Grave/feature number & Material & BC & BC/AD cal. \\
\hline 521_wood & Poz-64638 & gr. 12 & coffin & $1600 \pm 30 \mathrm{BP}$ & $399-539 \mathrm{AD}, 95.4 \%$ \\
519_wood & Poz-64639 & gr. 11 & coffin & $1570 \pm 30 \mathrm{BP}$ & $416-557 \mathrm{AD}, 95.4 \%)$ \\
1524_dog & Poz-64641 & f. 1524 & bone, dog & $1550 \pm 30 \mathrm{BP}$ & $423-574 \mathrm{AD}, 95.4 \%$ \\
573_h & Poz-64642 & gr. 55 & bone, human & $1630 \pm 30 \mathrm{BP}$ & $346-36 \mathrm{AD}, 95.4 \%$ \\
573_a & Poz-64644 & gr. 55 & bone, animal & $1505 \pm 30 \mathrm{BP}$ & $431-635 \mathrm{AD}, 95.4 \%)$ \\
1555_h & Poz-64645 & gr. 142 & bone, human & $1570 \pm 30 \mathrm{BP}$ & $416-557 \mathrm{AD}, 95.4 \%$ \\
1555_a & Poz-64646 & gr. 142 & bone, animal & $1970 \pm 30 \mathrm{BP}$ & $45 \mathrm{BC}-85 \mathrm{AD}, 95.4 \%$ \\
1333_barley & Poz-64640 & gr. 175 & caryopsis, barley & $75 \pm 30 \mathrm{BP}$ & $1690-1925 \mathrm{AD}, 95,4 \%$ \\
1491_coffee & UGAMS 20578 & gr. 31 & coffee bean & recent & recent \\
1204_fig & UGAMS 20579 & gr. 164 & seed, fig & $210 \mathrm{BP} \pm 25$ & $1646 \mathrm{AD}-$ recent, $93 \%$ \\
\hline
\end{tabular}

according to taxa was done with the help of a reference collection and standard identification literature (Greguss 1972; Schweingruber 1990). Charcoals were quantified as the number of analysed fragments.

Pollen samples were prepared by laboratory treatment of the sediment $\left(1 \mathrm{~cm}^{3}\right)$ using the standard method of $\mathrm{HCl}, \mathrm{HF}$, $\mathrm{KOH}$ and acetolysis (Erdtman 1960). The resulting macerated product was, due to a higher yield of palynomorphs, concentrated in a heavy liquid $\left(\mathrm{ZnCl}_{2}\right)$ and observed in this medium on a biological specimen slide $(26 \times 76 \mathrm{~mm})$ covered with a glass slip $(22 \times 22 \mathrm{~mm})$. Identification of palynomorphs and non-pollen objects was based on a wide range of publications, including Beug (2004), Boros, Járai-Komlódi (1975), Ellis, Ellis (1985), Erdtman (1957), Erdtman et al. (1961), Komárek, Jankovská (2001), Moore et al. (1991), Reille (1995), Thomma (2003), Van Geel, Aptroot (2006). The total pollen diagram was created using the POLPAL program (Walanus, Nalepka 1999). The basic sum of all the woody species (arboreal pollen - AP) as well as herbs (non-arboreal pollen - NAP) representing 100\% (total sum - TS) was used for calculation of the percentage of individual types. A portion of ferns was not included into the calculation, but it was evaluated.

Ten samples of organic remains - two samples of wood from coffins, three animal bones, two human bones, one carbonized caryopsis of barley, and two noncarbonized seeds (of fig and coffee) were radiocarbon dated using accelerator mass spectrometry at the Centre for Applied Isotope Studies, University of Georgia and Poznań Radiocarbon Laboratory (Figure 3; Table 3). Data were calibrated by OxCal v4.2.4 (Bronk Ramsey 2013) using the IntCal13 calibration curve (Reimer et al. 2013).

In order to consider the main patterns in the archaeobotanical datasets-in terms of position within the graves-multivariate statistical methods were used (Canoco v. 5; ter Braak, Šmilauer 2002). Logarithmic transformation of the percentage data and centering by species was used for all ordinations. Detrended Correspondence Analysis (DCA) was performed on the whole dataset, as the preliminary DCA showed that length of the gradient was sufficient (6.69 for macroremains and 3.79 for wood and charcoal). Canonical Correspondence Analysis (CCA) was used to test how much variability in the archaebotanical datasets can be explained by the position of the sample in the grave.

\section{Results}

Radiocarbon data obtained from the graves showed the complicated development of sediments inside them (Figure 3 and Table 3). An earlier occupation of the site was also reflected by residuals of ceramic vesels (Neolithic, Late Neolithic, Late Bronze Age and La Tène Period).

\subsection{Plant macroremains}

In total, 644 samples from the site were analysed for plant macroremains. Of these, 614 samples came from 53 graves (volume 15,351 litres) (Tables 1 and 2), 22 samples from seven settlement pits (volume 150 litres), and nine samples from the infill of the road (569 litres). More than 16,000 litres of sediments were floated. A total of 3,493 macroremains were counted (457 carbonized; 3,036 noncarbonized/waterlogged; Table 2). About 67 carbonized and 103 non-carbonized taxa were recorded (Tables 4, 5 and 6). Settlement features were dated to the Late Bronze Age or to "agricultural prehistory", and graves to the Migration Period, but many intrusions were also documented. The density of plant macroremains per litre of sediment in all samples was very low, but within groups of contexts (R, RS, J, S, JS, C, $\mathrm{X}$ ) it was similar (Table 2).

\subsubsection{Graves}

The average values of carbonized macroremains were similar for samples from coffins, from the bottoms of graves (R), grave backfills (J) and plunderers' shafts (S). In samples from boundary groups (RS and JS) the values were higher (Figure 4). Average values of non-carbonized macroremains were similarly low for samples from coffins and the bottoms of graves (R) and grave backfills (J). In samples from plunderers' shafts (S) and from the boundaries of plunderers' shafts (RS and JS), average values were higher (Figure 4). The structure of individual categories of samples was similar (Figure 5). Among carbonized macroremains, useful plants were dominant. Remains of weeds and ruderals were also 


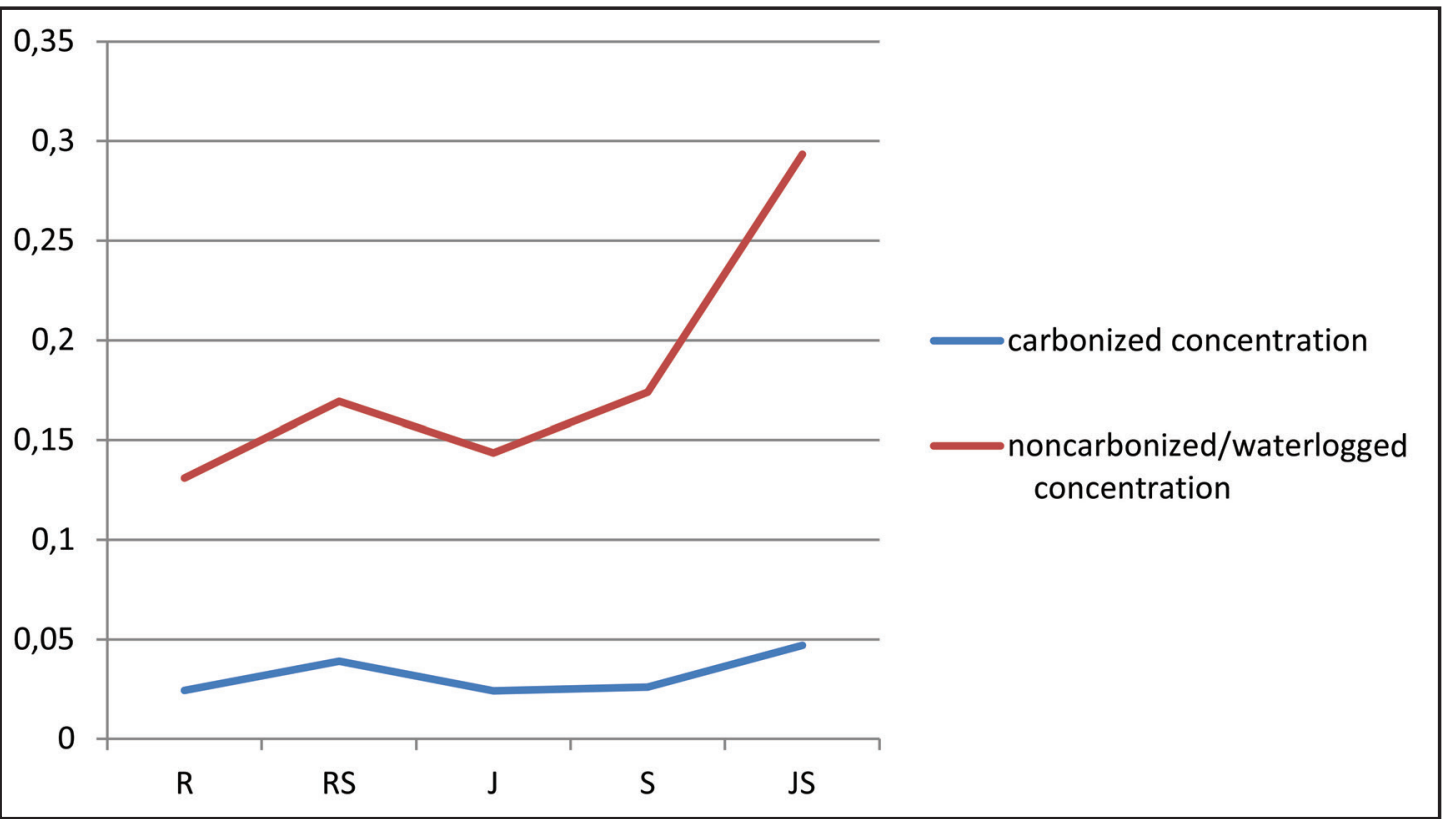

Figure 4. Prague Zličín; concentration of carbonized/non-carbonized plant macroremains (average number per litre of sediment) in individual parts of the graves (R - coffins, J - graves infill, S - looting shafts, RS and JS - borders between coffin/looting shaft or between coffin/grave infill).

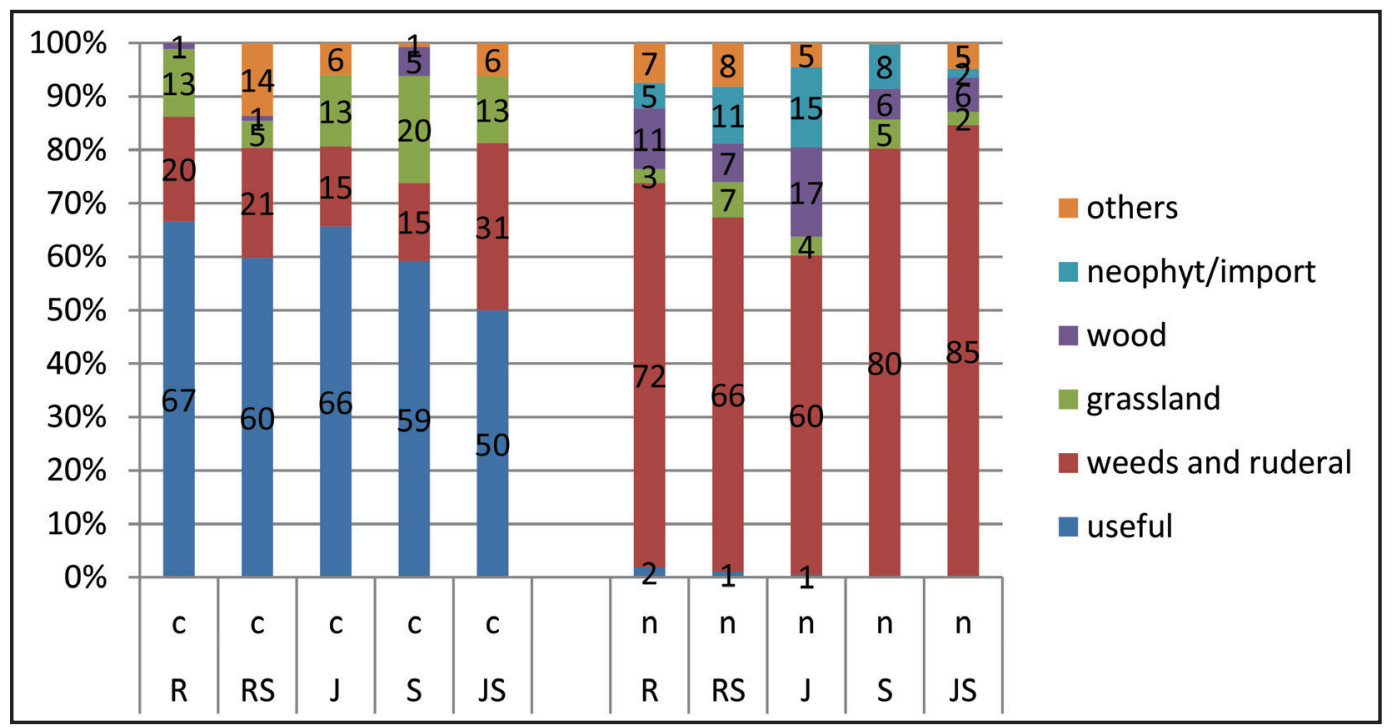

Figure 5. Prague Zličín; reconstruction of individual eco-groups among the carbonized (c)/non-carbonized (n) plant macroremains in individual parts of the graves (R - coffins, J - graves infill, S - looting shafts, RS and JS - borders between coffin/looting shaft or between coffin/grave infill; depicted in percentages).

frequently reflected. Remains of plants which grow in different types of grasses were common. Remains of wood plants were rare in all categories. Among non-carbonized macroremains, weeds and ruderals were dominant. Remains of plants typical for forests and grasslands were present. The category of neophytes, or imports, is problematic and minimal. Remains of useful plants are rare.

Remains of carbonized useful plants are similar in each category (Table 4). The remains of cereals (Hordeum vulgare, Panicum miliaceum, Triticum aestivum, cf. Triticum dicoccum, Triticum spelta, Secale cereale, Avena sp.) are more numerous then remains of pulses, except for the boundary area between grave backfilling and plunderers' shafts, where pulses prevail (Figure 6). Pea (Pisum sativum, Vicia/Pisum) is most numerous, followed by lentil (Lens culinaris), but their frequency in individual categories is similar. Seeds of Faba bean (cf. Vicia faba) were found only in one sample from a plunderer's shaft.

Damage to cereal grains due to poor preservation was high. In assemblages from R, RS and J 50\% of cereal grains (Cerealia) could not be determined (Figure 7). The grains of barley (Hordeum vulgare/ Hordeum vulgare var. vulgare) were the most abundant in all contexts. Also present in all contexts, though in smaller quantities, were grains of 
Table 4. Prague Zličín; remains of carbonized useful plants and non-carbonized useful plants, and neophytes of imports, in individual parts of the graves (R - coffins, J - graves infill, S - looting shafts, RS and JS - borders between coffin/looting shaft or between coffin/grave infill).

\begin{tabular}{|c|c|c|c|}
\hline & \multirow{2}{*}{$\begin{array}{c}\text { Carbonized } \\
\text { Useful }\end{array}$} & \multicolumn{2}{|c|}{ Non-carbonized } \\
\hline & & Useful & Neofyt/import \\
\hline $\mathrm{R}$ & $\begin{array}{l}\text { Avena } \mathrm{sp} .1 \text {, Cerealia } 16 \text {, Cerealia/Fabaceae (pulses) } 1, \text { Hordeum } \\
\text { vulgare } 4 \text {, Hordeum vulgare var. vulgare } 8, \text { Lens culinaris } 2, \\
\text { Panicum miliaceum } 7, \text { Panicum/Setaria } 1, \text { Pisum sativum } 2 \text {, cf. } \\
\text { Secale cereale } 1, \text { Triticum sp. } 1 \text {, Triticum aestivum 3, Triticum cf. } \\
\text { spelta } 2 \text {, Vicia/Pisum } 10\end{array}$ & $\begin{array}{l}\text { Brassica campestris } 1 \text {, Carum carvi } 2, \\
\text { Cerealia (straw) } 1, \text { Hordeum vulgare var. } \\
\text { vulgare } 1, \text { Hordeum vulgare var. vulgare } \\
\text { (rachis) } 2 \text {, Humulus lupulus } 1 \text {, } \\
\text { Panicum/Setaria } 1, \text { Papaver somniferum } 1 \\
\end{array}$ & $\begin{array}{l}\text { Amaranthus sp. } 24 \text {, } \\
\text { Helianthus sp. } 2\end{array}$ \\
\hline RS & $\begin{array}{l}\text { Cerealia } 22, \text { Hordeum vulgare } 5 \text {, Hordeum vulgare var. vulgare } 10, \\
\text { Lens culinaris } 1 \text {, Panicum miliaceum } 5 \text {, Pisum sativum } 1 \text {, cf. Secale } \\
\text { cereale } 1 \text {, Triticum } \text { cf. aestivum } 1 \text {, Triticum spelta } 1 \text {, Triticum spelta } \\
\text { (spikelet fork) } 1 \text {, Vicia/Pisum } 22\end{array}$ & $\begin{array}{l}\text { Carum carvi 2, Cerealia 1, Cerealia (straw) 2, } \\
\text { cf. Humulus lupulus } 1\end{array}$ & $\begin{array}{l}\text { Amaranthus sp. } 39 \text {, } \\
\text { Coffea } \text { cf. arabica } 1 \text {, } \\
\text { Helianthus } \text { sp. } 9 \text {, } \\
\text { Prunus persica }\end{array}$ \\
\hline $\mathrm{J}$ & $\begin{array}{l}\text { Avena sp. 1, Cerealia } 15 \text {, Hordeum vulgare (rachis) } 1 \text {, Hordeum } \\
\text { vulgare 5, Hordeum vulgare var. vulgare } 6 \text {, Triticum sp. 1, Triticum } \\
\text { cf. aestivum } 1 \text {, cf. Triticum dicoccum } 4 \text {, Lens culinaris } 1 \text {, Pisum } \\
\text { sativum 4, Vicia cf. faba } 1 \text {, Vicia/Pisum } 4\end{array}$ & $\begin{array}{l}\text { Carum carvi } 1 \text {, Hordeum vulgare var. vulgare } \\
\text { (rachis) } 1\end{array}$ & $\begin{array}{l}\text { Amaranthus sp. } 57, \text { Ficus } \\
\text { carica } 1 \text {, Helianthus } \mathrm{sp} .1 \text {, } \\
\text { Pistacia vera } 1\end{array}$ \\
\hline $\mathrm{S}$ & $\begin{array}{l}\text { Avena } \text { sp. 1, Cerealia } 39 \text {, Pisum/Vicia } 1 \text {, Hordeum vulgare (rachis) } \\
1 \text {, Hordeum vulgare } 8 \text {, Hordeum vulgare var. vulgare } 1 \text {, Lens } \\
\text { culinaris } 2 \text {, Panicum miliaceum 9, Panicum/Setaria } 1 \text {, Pisum } \\
\text { sativum } 3 \text {, Triticum } \text { sp. 1, Triticum aestivum } 3 \text {, Triticum compactum } \\
1 \text {, cf. Triticum dicoccum 1, Vicia/Pisum } 5\end{array}$ & Avena sp. 1 , Hordeum vulgare var. vulgare 1 & $\begin{array}{l}\text { Amaranthus sp. 61, } \\
\text { Helianthus sp. 6, Thuja } \\
\text { plicata } 1\end{array}$ \\
\hline JS & $\begin{array}{l}\text { Cerealia 1, Hordeum vulgare 1, Pisum sativum 2, Triticum sp . 1, } \\
\text { Vicia/Pisum } 3\end{array}$ & & Amaranthus sp. 2 \\
\hline
\end{tabular}

Figure 6. Prague Zličín; relation among remains of cereals and pulses in individual parts of the graves $(\mathrm{R}-$ coffins, $\mathrm{J}$ - graves infill, S - looting shafts, RS and JS - borders between coffin/looting shaft or between coffin/grave infill).
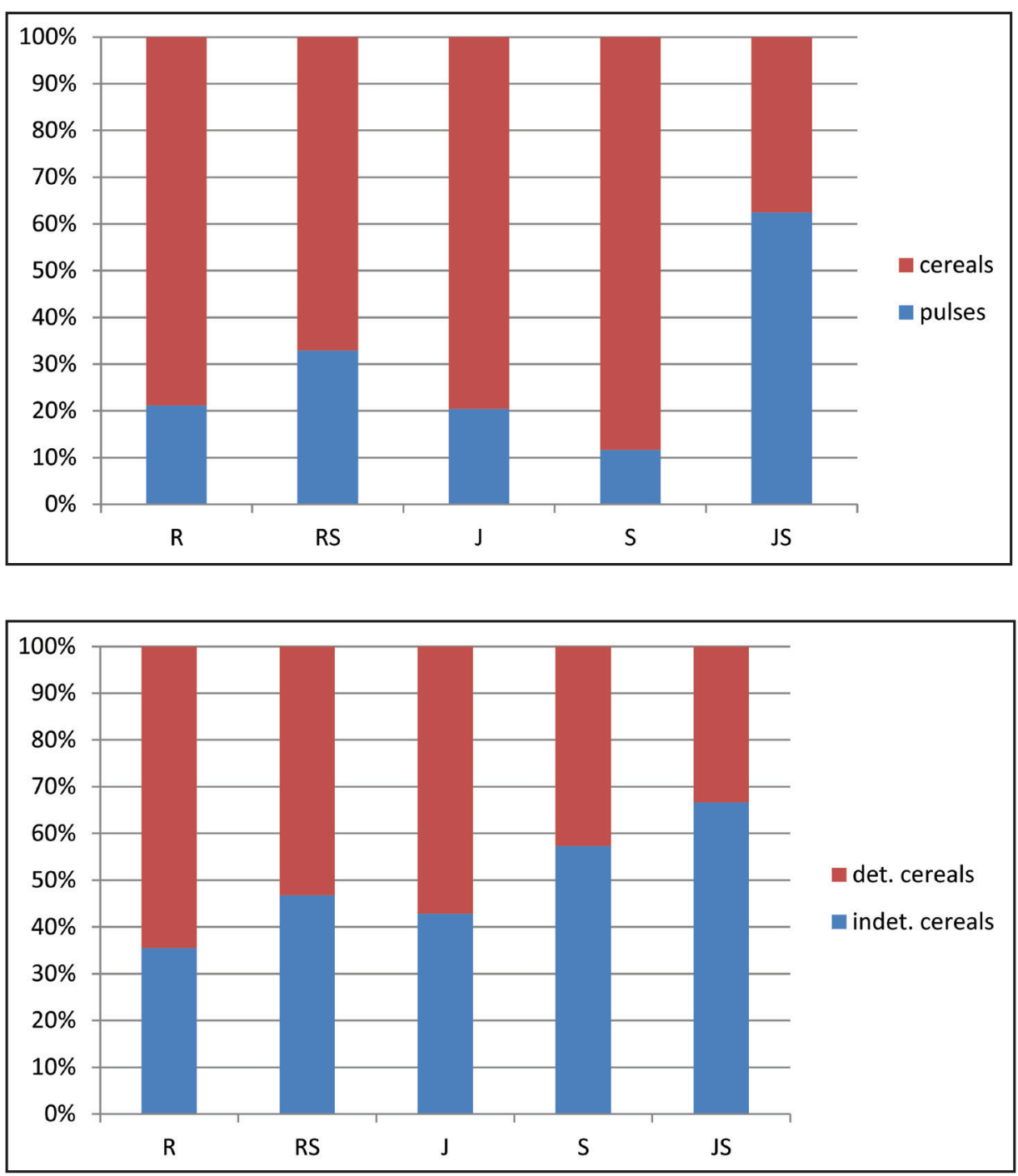

Figure 7. Prague Zličín; relation among determined and undetermined remains of cereals in individual parts of the graves $(\mathrm{R}$ - coffins, J - graves infill, S - looting shafts, RS and JS - borders between coffin/looting shaft or between coffin/grave infill). 


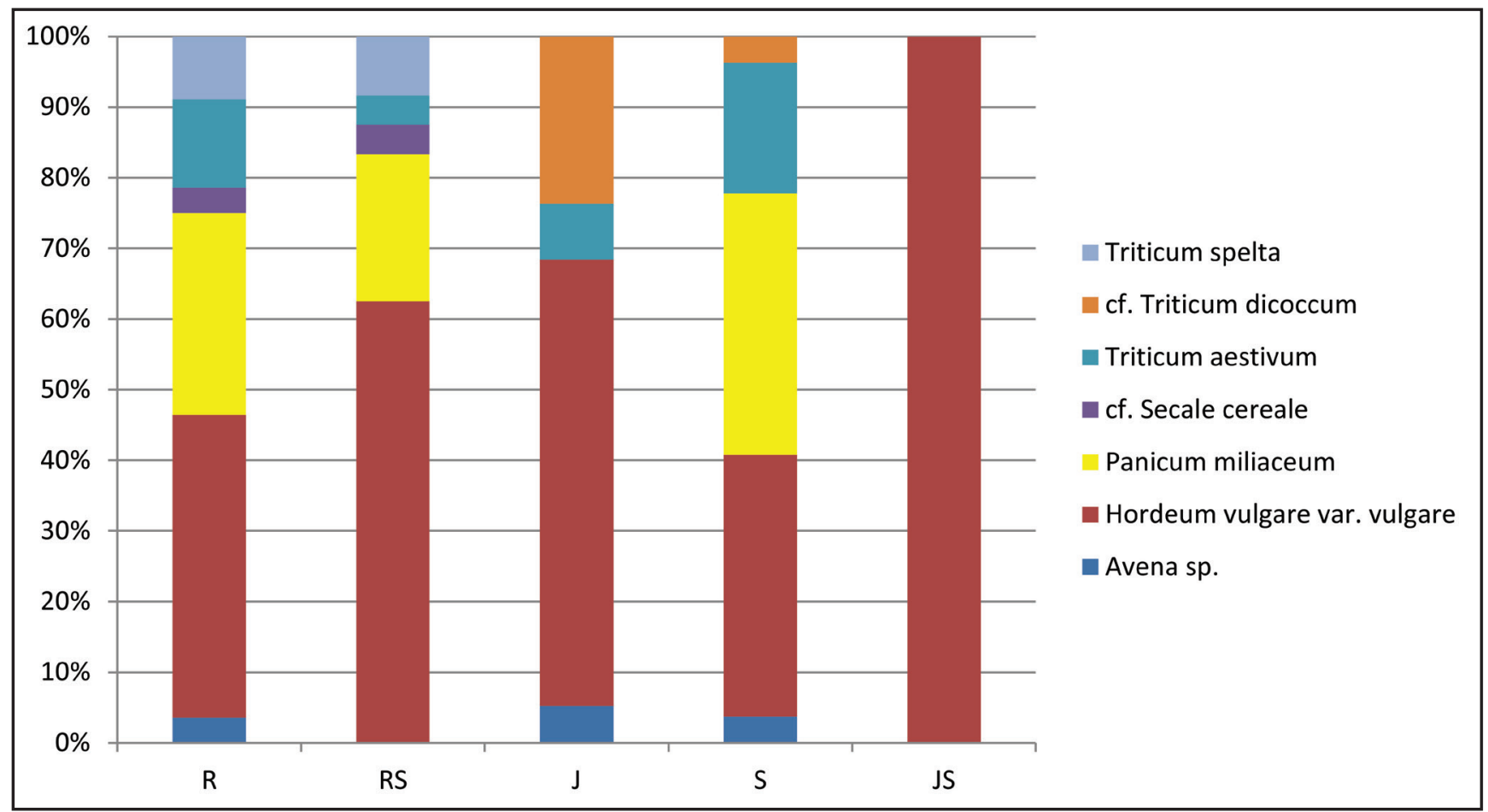

Figure 8. Prague Zličín; structure of cereals in individual parts of the graves (R - coffins, J - graves infill, $\mathrm{S}$ - looting shafts, RS and JS - borders between coffin/looting shaft or between coffin/grave infill, depicted in percentages).

Table 5. Prague Zličín; carbonized and non-carbonized remains of weeds and ruderals in individual parts of the graves (R - coffins, J - graves infill, S looting shafts, RS and JS - borders between coffin/looting shaft or between coffin/grave infill).

\begin{tabular}{|c|c|c|}
\hline & Carbonized & Noncarbonized \\
\hline & & Weeds and ruderal \\
\hline $\mathrm{R}$ & $\begin{array}{l}\text { Agrostemma githago } 1 \text {, Chenopodium } \\
\text { album } 11, \text { Chenopodium hybridum } 1, \\
\text { Malva } \text { cf. neglecta } 1 \text {, Brassica } \text { sp. } 1 \text {, } \\
\text { Galium sp. } 1 \text {, Lamiaceae } 1\end{array}$ & $\begin{array}{l}\text { Aethusa cynapium 5, Arenaria serpyllifolia } 2 \text {, Atriplex sp. 19, Avena fatua (spikelet) } 1 \text {, } \\
\text { Echinochloa crus-galli } 5 \text {, Fallopia convolvulus } 19 \text {, Fumaria officinalis } 10 \text {, Galium sp. } \\
\text { 2, Chenopodium album } 213 \text {, Chenopodium ficifolium } 3 \text {, Chenopodium sp. 2, Persicaria } \\
\text { hydropiper } 1 \text {, Polygonaceae } 2 \text {, Polygonum aviculare } 51 \text {, Setaria sp. } 1 \text {, Setaria viridis } 3 \text {, } \\
\text { Silene alba } 1 \text {, Silene cf. noctiflora } 3 \text {, Silene sp. } 11 \text {, Sinapis arvensis } 1 \text {, Stellaria media } 1 \text {, } \\
\text { Tripleurospermum maritimum } 2 \text {, Veronica hederifolia } 27 \text {, Veronica sp. } 8\end{array}$ \\
\hline RS & $\begin{array}{l}\text { Galium sp. } 1 \text {, Galium spurium } 2 \text {, } \\
\text { Chenopodium album } 8 \text {, Chenopodium } \mathrm{sp.} \\
8 \text {, Polygonum aviculare } 1 \text {, Setaria } \mathrm{sp.} 2 \text {, } \\
\text { Silene cf. alba } 2\end{array}$ & $\begin{array}{l}\text { Aethusa cynapium } 6 \text {, Anthriscus caucalis } 1 \text {, Atriplex sp. 17, Echinochloa crus-galli } \\
\text { 14, Fallopia convolvulus } 16 \text {, Fumaria officinalis } 16, \text { Galium spurium } 1 \text {, Chenopodium } \\
\text { album } 164 \text {, Chenopodium ficifolium } 1 \text {, Chenopodium sp. 4, Lactuca seriola } 1 \text {, Neslia } \\
\text { paniculata } 2 \text {, Panicum/Echinochloa/Setaria fragment 1, Polygonaceae 2, Polygonum } \\
\text { aviculare 32, Setaria sp. 2, Setaria viridis } 1 \text {, Silene sp. 3, Stellaria media } 2 \text {, Thlaspi } \\
\text { arvense } 2 \text {, Tripleurospermum maritimum } 9 \text {, Veronica hederifolia } 16\end{array}$ \\
\hline & $\begin{array}{l}\text { Fallopia convolvulus } 1 \text {, Chenopodium } \\
\text { album } 6 \text {, Chenopodium } \mathrm{sp} .1 \text {, Silene } \mathrm{cf} . \\
\text { alba } 1 \text {, Solanum nigrum } 1\end{array}$ & $\begin{array}{l}\text { Aethusa cynapium 4, Atriplex sp. 24, Ballota nigra 1, Brassicaceae 1, Echinochloa } \\
\text { crus-galli } 1 \text {, Fallopia convolvulus 9, Fumaria officinalis 9, Chenopodium album 132, } \\
\text { Chenopodium ficifolium 2, Chenopodium sp. 8, Lactuca sp. 1, Neslia paniculata } 1 \text {, } \\
\text { Papaver rhoeas 2, Polygonum aviculare 13, Polygonaceae 2, Setaria sp. 1, Silene alba 1, } \\
\text { Silene sp. 8, Stellaria media 2, Thlaspi arvense 1, Urtica dioica } 1 \text {, Veronica hederifolia } \\
\text { 12, Veronica sp. } 1\end{array}$ \\
\hline S & $\begin{array}{l}\text { Anagallis arvensis } 1 \text {, Galium sp. } 2 \text {, } \\
\text { Galium spurium } 2 \text {, Chenopodium } \\
\text { album } 1 \text {, Chenopidium ficifolium } 1 \text {, } \\
\text { Chenopodium hybridum } 1 \text {, Chenopodium } \\
\text { sp. } 2 \text {, Neslia paniculata } 3 \text {, Polygonum } \\
\text { aviculare } 1 \text {, Polygonum lapathifolium } 1 \text {, } \\
\text { Solanum nigrum } 1, \text { Solanum dulcamara } \\
1 \text {, Veronica hederifolia } 2\end{array}$ & $\begin{array}{l}\text { Aethusa cynapium } 13 \text {, Arenaria serpyllifolia } 1,1 \text {, Atriplex sp. } 24 \text {, Echinochloa crus-galli } \\
5 \text {, Fallopia convolvulus } 28 \text {, Fumaria officinalis } 22 \text {, Galium sp. } 2 \text {, Chenopodium album } \\
407, \text { Chenopodium ficifolium } 3 \text {, Chenopodium hybridum } 1 \text {, Chenopodium sp. } 3 \text {, Lactuca } \\
\text { seriola } 1 \text {, Polygonum aviculare } 57 \text {, Polygonum aviculare (mineralised) } 2 \text {, Polygonum } \\
\text { lapatifolium } 1 \text {, Setaria viridis } 1 \text {, Setaria/Echinochloa sp. } 1 \text {, Silene sp. } 29 \text {, Stellaria media } \\
2 \text {, Thlaspi arvense } 4 \text {, Tripleurospermum maritimum } 2 \text {, Veronica hederifolia } 51 \text {, Veronica } \\
\text { sp. } 2\end{array}$ \\
\hline JS & $\begin{array}{l}\text { Fallopia convolvulus } 1 \text {, Chenopodium } \\
\text { album } 3 \text {, Viola } \text { sp. } 1\end{array}$ & $\begin{array}{l}\text { Echinochloa crus-galli } 1, \text { Euphorbia helioscopia } 1 \text {, Fallopia convolvulus } 10, \text { Fumaria } \\
\text { officinalis } 2 \text {, Chenopodium album } 63 \text {, Polygonum aviculare } 19 \text {, Setaria sp. 1, Silene sp. } \\
1 \text {, Veronica hederifolia } 6 \text {, Veronica sp. } 1\end{array}$ \\
\hline
\end{tabular}


naked wheat (Triticum aestivum/compactum), as well as oat (Avena sp.). Millet (Panicum miliaceum) was concentrated in samples from coffins and the bottoms of graves $(\mathrm{R})$, in the boundary area between coffins and plunderers' shafts (RS), and from shafts (S), whereas rye (cf. Secale cereale) and spelt (Triticum cf. spelta) were found only in side coffins (R and RS), and emmer (cf. Triticum dicoccum) was only in grave infills and in shafts (J and S; Figure 8).

Remains of non-carbonized useful plants were not numerous: amounting to about $2 \%$ of the samples from the coffins (R and RS). In other samples the ratio of useful plants was under $1 \%$ of non-carbonized remains (Table 4). Remains of barley (Hordeum vulgarel Hordeum vulgare var. vulgare) were found in all categories $(\mathrm{R}, \mathrm{S}, \mathrm{J})$, Cerealia found in the coffin samples (R and RS), and remains of oats (Avena sp.) found in the shafts (S). Seeds of Carum carvi were found in coffins (R and RS) and in infills (J). Seeds of Humulus lupulus ( $\mathrm{R}$ and $\mathrm{RS}$ ), as well as Brassica campestris and Papaver somniferum (R), were only found inside coffins.

Some remains from the category of imports/neophytes are considered as useful plants. Amaranthus sp. and Helianthus sp. were found in samples from all categories (R, RS, J, S, JS). Remains of Coffea cf. arabica and Prunus persica were found in the RS category, while remains of Ficus carica (Figure 9) and Pistacia vera were only found in the infill of graves $(\mathrm{J})$, while the remains of Thuja plicata were documented in plunderers' shafts $(\mathrm{S})$.

Carbonized remains of weeds and ruderal plants were frequently reflected. Among non-carbonized macroremains, the category of weeds and ruderal plants was dominant (for details, see Table 5). Among the carbonized macroremains, in many determinations it was only possible to estimate to the genus because of the degradation of individual seeds and fruits.

A list of plant remains which can grow in different types of grasslands is in Table 6 . The concentration of carbonized remains was generally higher than non-carbonized remains (categories R, J, S and JS).

Non-carbonized remains of woody plants were present more frequently than carbonized macroremains (for details see Table 6). Fragments of non-carbonized needles (Abies alba, Picea abies, Abies alba) were present in all categories except JS. Seeds of Betula pendula were frequently present among non-carbonized remains, but were rare among carbonized remains (only R). A non-carbonized nut of Tilia sp. was found in grave infill. A carbonized seed of Rubus sp. and non-carbonized seeds of Sambucus nigra, S. racemosa and Sambucus sp., as well as remain of Galeopsis tetrahit/ bifida, were found in samples from plunderers' shafts.

Many plant remains were not able to be included in any eco-groups due to unclear identification - mostly because

Table 6. Prague Zličín; remains of carbonized and non-carbonized remains of grasslands, forest, and non-categorized remains in individual parts of the graves (R - coffins, J - graves infill, S - looting shafts, RS and JS - borders between coffin/looting shaft or between coffin/grave infill).

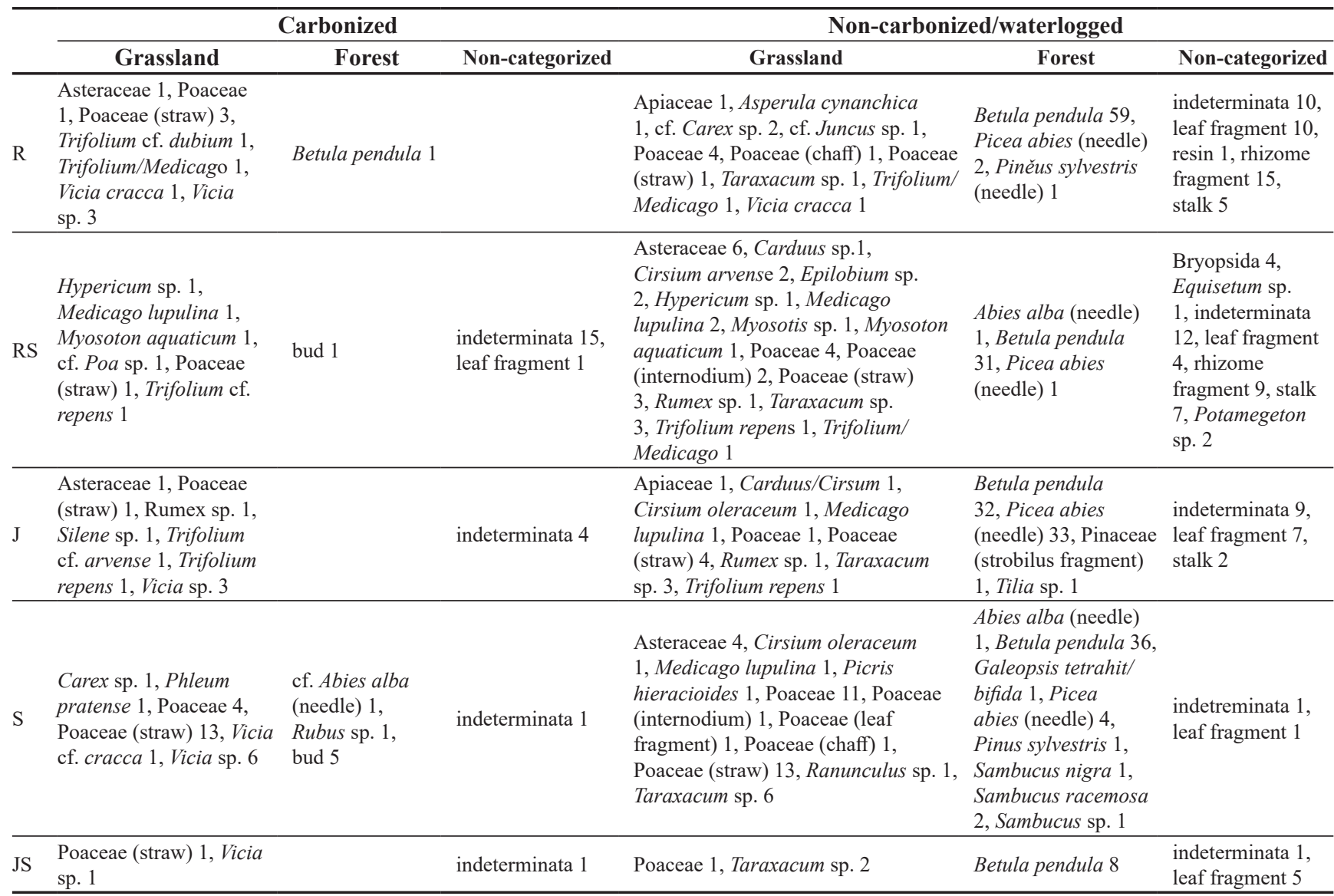



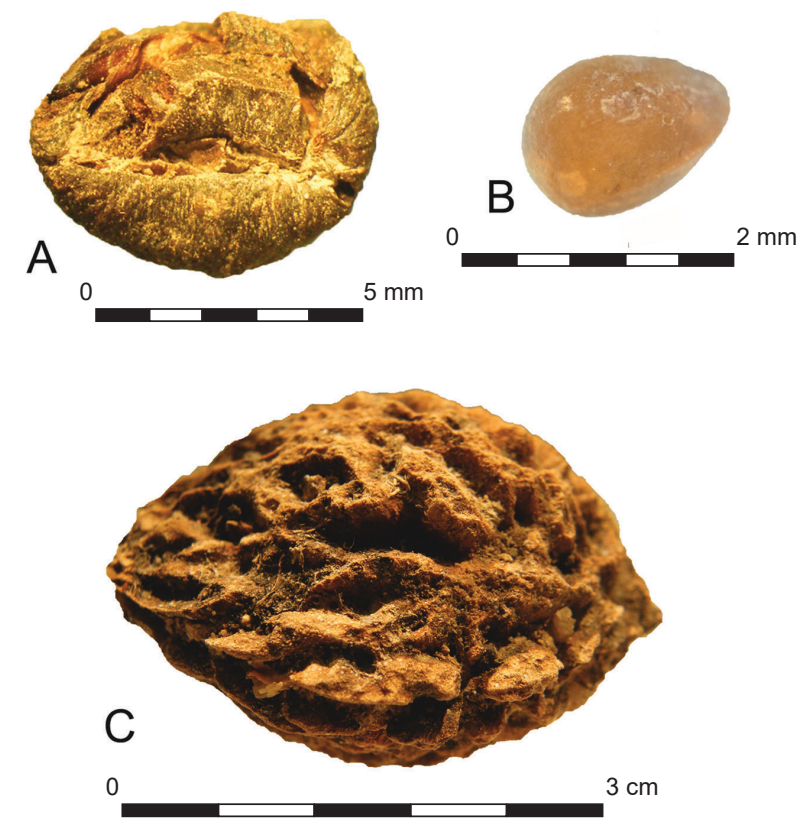

Figure 9. Prague Zličín; selected plant macroremains. A - Coffea cf. arabica, B - Ficus carica, C - Prunus persica.

of the fragmentation and degradation of individual remains. Among these were indeterminate seeds/fruits, fragments of leaves, stalks and rhizomes (Table 6).

\subsubsection{Non-funerary deposits}

Only 24 specimens of carbonized macroremains, dated to "agricultural prehistory", were present in the samples from the non-funerary settlement deposits. Useful plants caryopsis of barley (Hordeum vulgare var. vulgare, Hordeum vulgare), indeterminate Cerealia, seeds of lentil (Lens culinaris) and pea (Pisum sativum, Vicia/Pisum) - formed half of the assemblage. Wild plants were represented by two (ruderal) taxa-Chenopodium album and Sambucus sp.

The age of non-carbonized macroremains (589 specimens), represented mainly by ruderals, is uncertain. Most of the assemblage was formed of seeds of the neophytic plant Amaranthus sp. (497) and Chenopodium album (43). Other taxa - usually considered as weeds of arable land - such as Aethusa cynapium, Atriplex sp., Fallopia convolvulus, Fumaria officinalis, Poaceae, Polygonum aviculare, Rumex sp., Silene sp., Veronica hederifolia were rare. Forest species were represented exclusively by finds of Picea abies (15 needle fragments), and grassland vegetation by Stellaria graminea. Samples from trackways (roads) yielded only a few noncarbonized specimens of Amaranthus sp. (4), Fallopia convolvulus (2), and Chenopodium album (1) of unknown date.

Canonical Correspondence Analysis (CCA) significantly supported the differences in the spectrum of species of plant macroremains, wood, and charcoal pieces in individual parts of the graves (wood/charcoal dataset: $\mathrm{p}=0.021, \mathrm{~F}=1.7$; macroremains dataset: $p=0.002, F=1.9$ ). It is noticeable that a significant part of the non-carbonized macroremains correlated with the border between coffins and grave infills

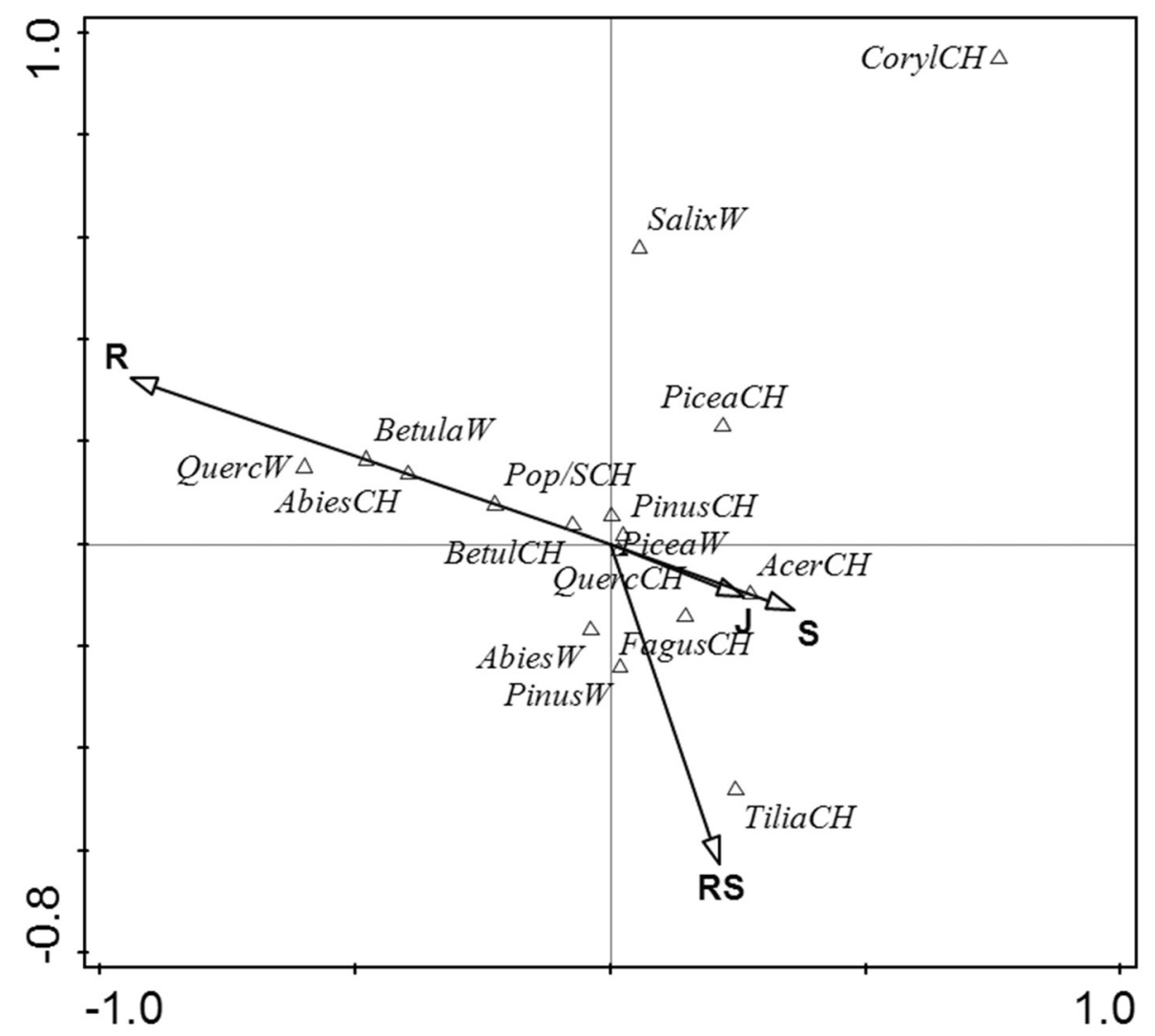

Figure 10. Prague Zličín; Canonical Correspondence Analysis (CCA) of charcoal/ wood dataset. 
Figure 11. Prague Zličín; Canonical Correspondence Analysis (CCA) of macroremains dataset.

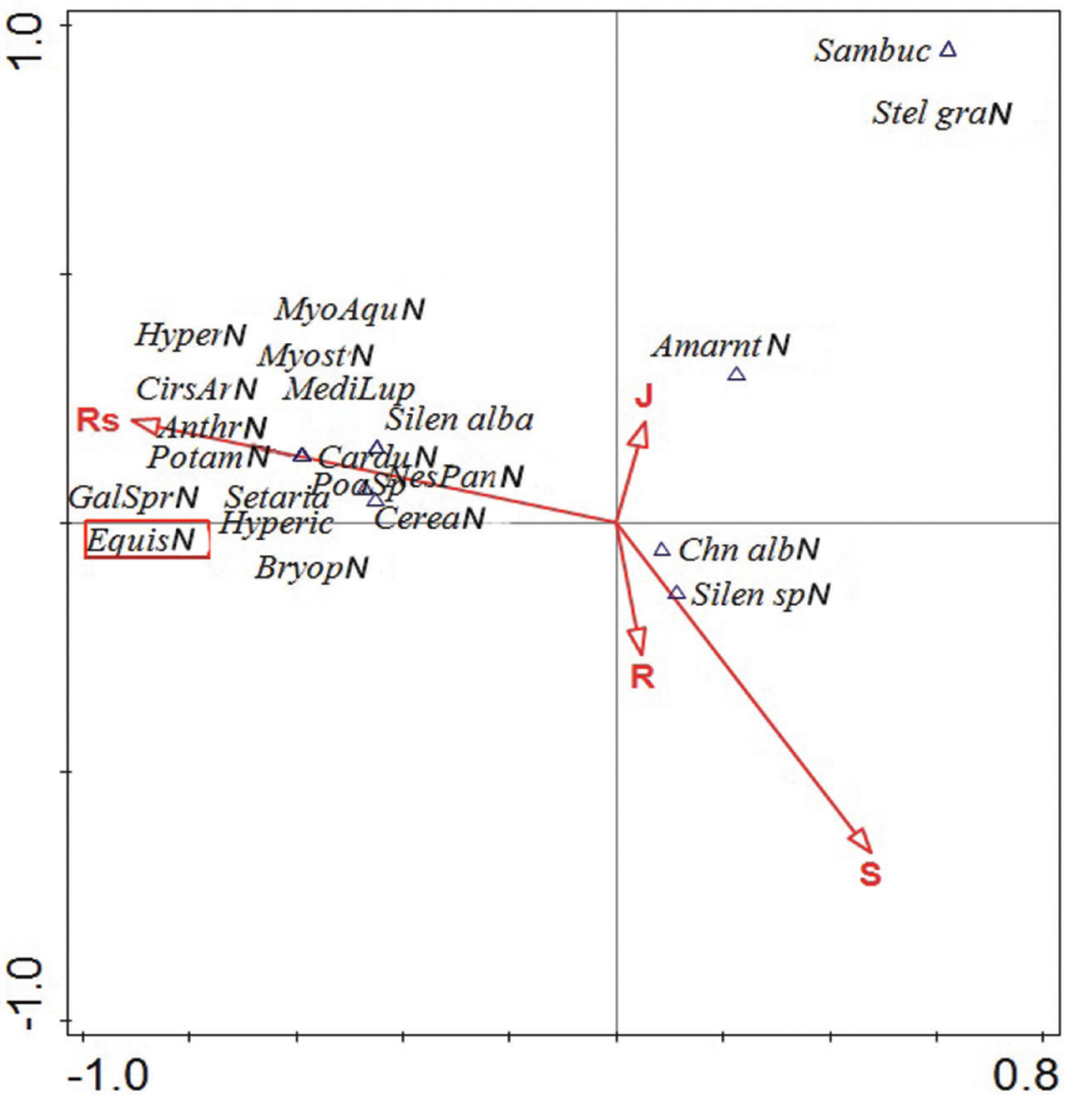

(RS) and, by contrast, is minimally connected with coffins (R) and infill (S) (Figures 10 and 11). Non-carbonized macroremains probably sedimented after the looting of the graves, when the looting shafts were open.

\subsection{Charcoal and wood}

The samples from the graves yielded 3017 charcoal records (252 samples from 49 graves, Table 10). The charcoal samples are characterized by the dominance of Quercus and Pinus, and the less common presence of Fagus sylvatica (Table 7, Figure 12).

The occurrence of Abies, Acer, Betula, Corylus, Picea, Salix/Populus, and Tilia charcoal pieces was very rare. The species composition of the specific parts of graves was recorded as relatively analogous. Among the uncharred wood fragments recovered from graves, with a total of

Table 7. Prague Zličín; charcoal and wood in individual parts of the graves ( $\mathrm{R}$ - coffins, $\mathrm{J}$ - graves infill, $\mathrm{S}$ - looting shafts, RS and JS - borders between coffin/looting shaft or between coffin/grave infill; $\mathrm{CH}$ - charcoal pieces, $\mathrm{W}$ - wood).

\begin{tabular}{|c|c|c|c|c|c|}
\hline & $\mathbf{J}$ & $\mathbf{R}$ & JS & $\mathbf{S}$ & RS \\
\hline Abies $\mathrm{CH}$ & & 8 & & 2 & \\
\hline Fagus $\mathrm{CH}$ & 2 & 6 & & 29 & 11 \\
\hline Acer $\mathrm{CH}$ & & & & 1 & \\
\hline Betula CH & 4 & 28 & & 28 & 7 \\
\hline Corylus $\mathrm{CH}$ & 1 & & & 1 & \\
\hline Picea $\mathrm{CH}$ & 2 & 4 & & 3 & 2 \\
\hline Pinus $\mathrm{CH}$ & 52 & 480 & 14 & 358 & 209 \\
\hline Pop/Salix $\mathrm{CH}$ & & 7 & & 6 & \\
\hline Quercus CH & 163 & 708 & 15 & 564 & 299 \\
\hline Tilia $\mathrm{CH}$ & & & & 1 & 2 \\
\hline Abies $W$ & 10 & 55 & & 29 & 42 \\
\hline Betula $W$ & & 4 & & 1 & \\
\hline Picea $W$ & 7 & 71 & 1 & 71 & 11 \\
\hline Pinus $W$ & 1 & 12 & & 28 & 51 \\
\hline Quercus $W$ & & 127 & & & 7 \\
\hline Salix $W$ & & 7 & & 4 & \\
\hline
\end{tabular}




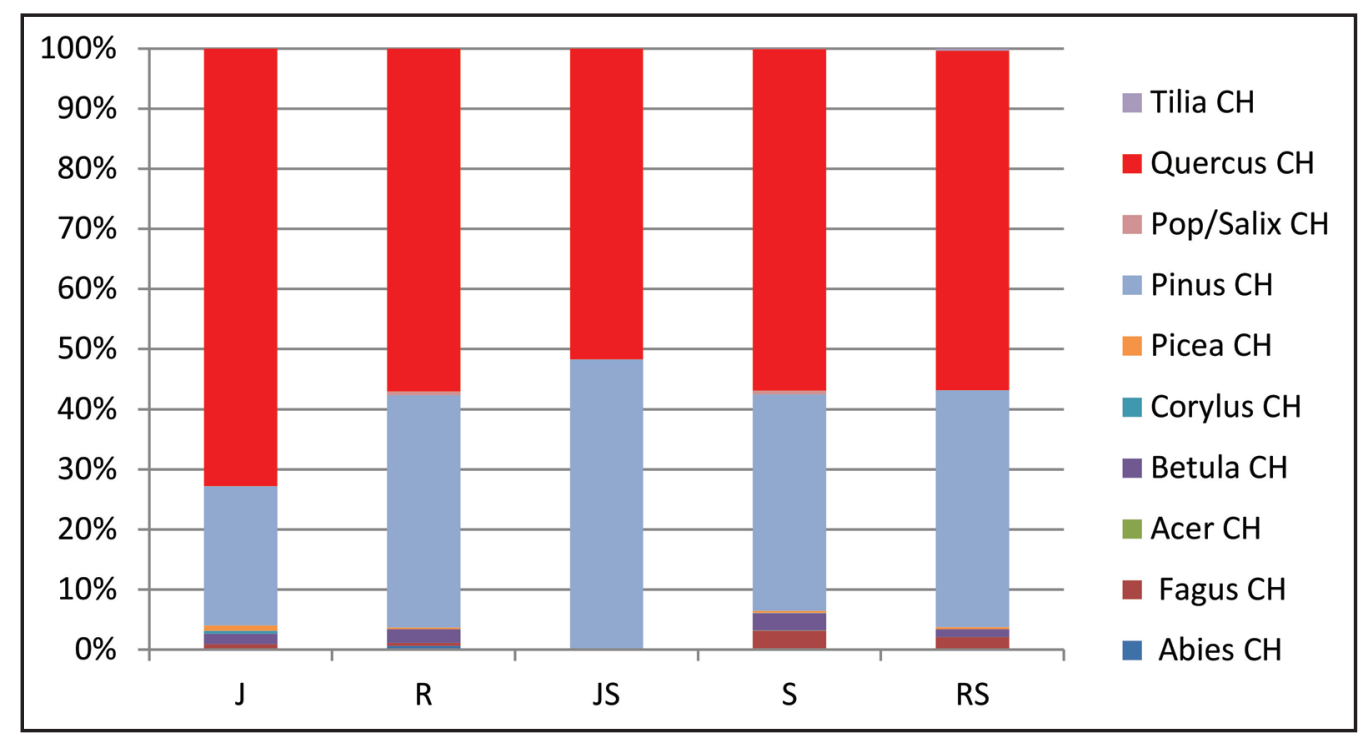

Figure 12. Prague Zličín; charcoal structure in individual parts of the graves ( $\mathrm{R}$ - coffins, $\mathrm{J}$ - graves infill, $\mathrm{S}$ - looting shafts, RS and JS - borders between coffin/looting shaft or between coffin/grave infill, depicted in percentages).

539 determinations, Picea, Pinus, Abies and Quercus were commonly recorded and Salix and Betula were sporadic (Table 7, Figure 13). These results document the selection of wood for various purposes. The highest quantity of wood corresponds with coffin parts (cf. Novák 2009). The characteristic indication of the coffins was the higher abundance of Quercus wood (Figure 10). In graves nos. 9, 11 , and 12 the larger remains of oak wooden coffins were documented in situ. Unfortunately, the number of preserved annual rings was insufficient for dendrochronological dating. Conifer wood was recorded in much higher quantities then the wood of deciduous trees.

From the non-funerary deposits, samples were collected from the road and sunken features. Most of the 133 charcoal pieces from the "road" were determined as Pinus (127).
Quercus (3) and Corylus (3) were identified sporadically. Other settlement features yielded 110 charcoal pieces and 11 wood fragments; among these Quercus was dominant (79) and Pinus (24) very often present. Charcoal pieces of Fagus, Betula, Corylus and Picea were recorded only sporadically. The samples from settlement features contained just a few uncharred wood fragments of Picea (5) and Salix (6).

\subsection{Pollen}

The frequency of pollen in samples was low (for selected pollen grains, see Figure 14). There are only 36 positive samples (Table 8) and only four samples contained more than 100 palynomorphs: grave 120 (sample 399, bottom of the grave); grave 123 (sample 506; bottom of the grave, by the cranium); grave 123 (sample 507, bottom of the coffin,

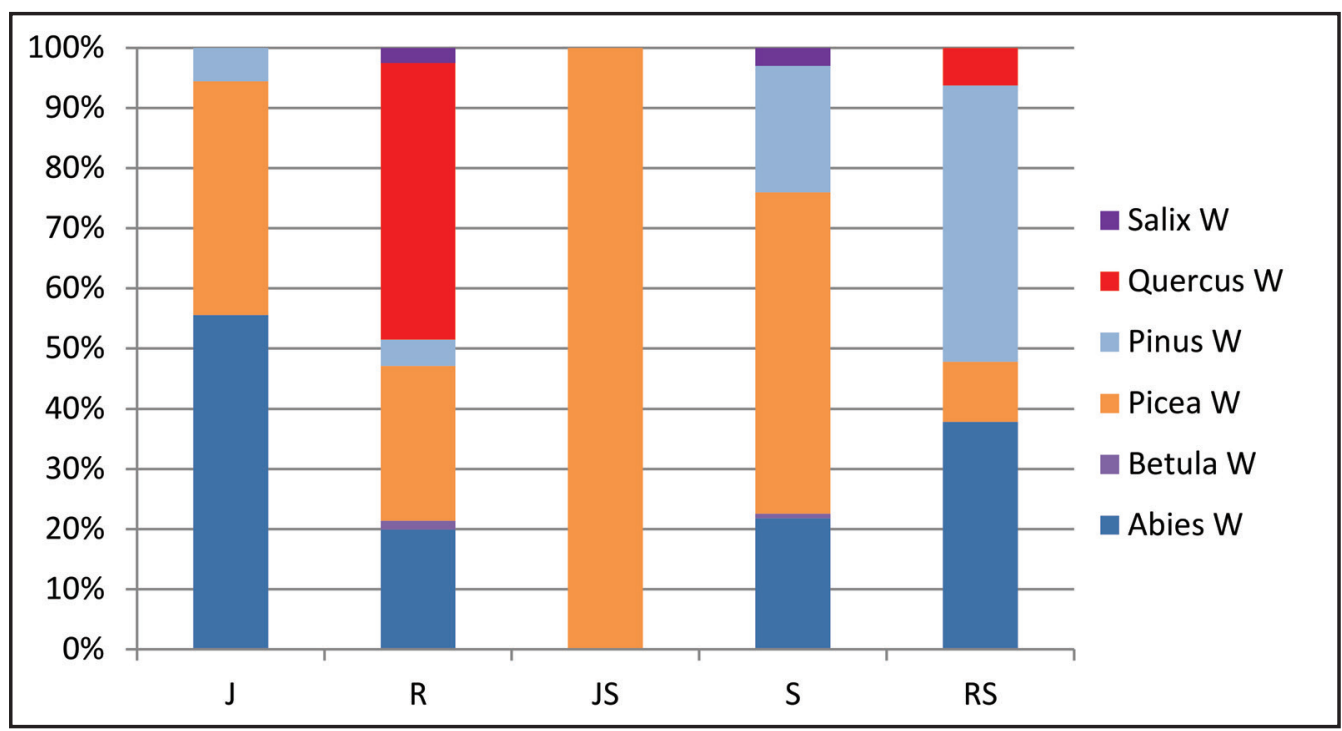

Figure 13. Prague Zličín; wood structure in individual parts of the graves ( $\mathrm{R}$ - coffins, $\mathrm{J}$ - graves infill, $\mathrm{S}$ - looting shafts, RS and JS - borders between coffin/looting shaft or between coffin/grave infill, depicted in percentages). 


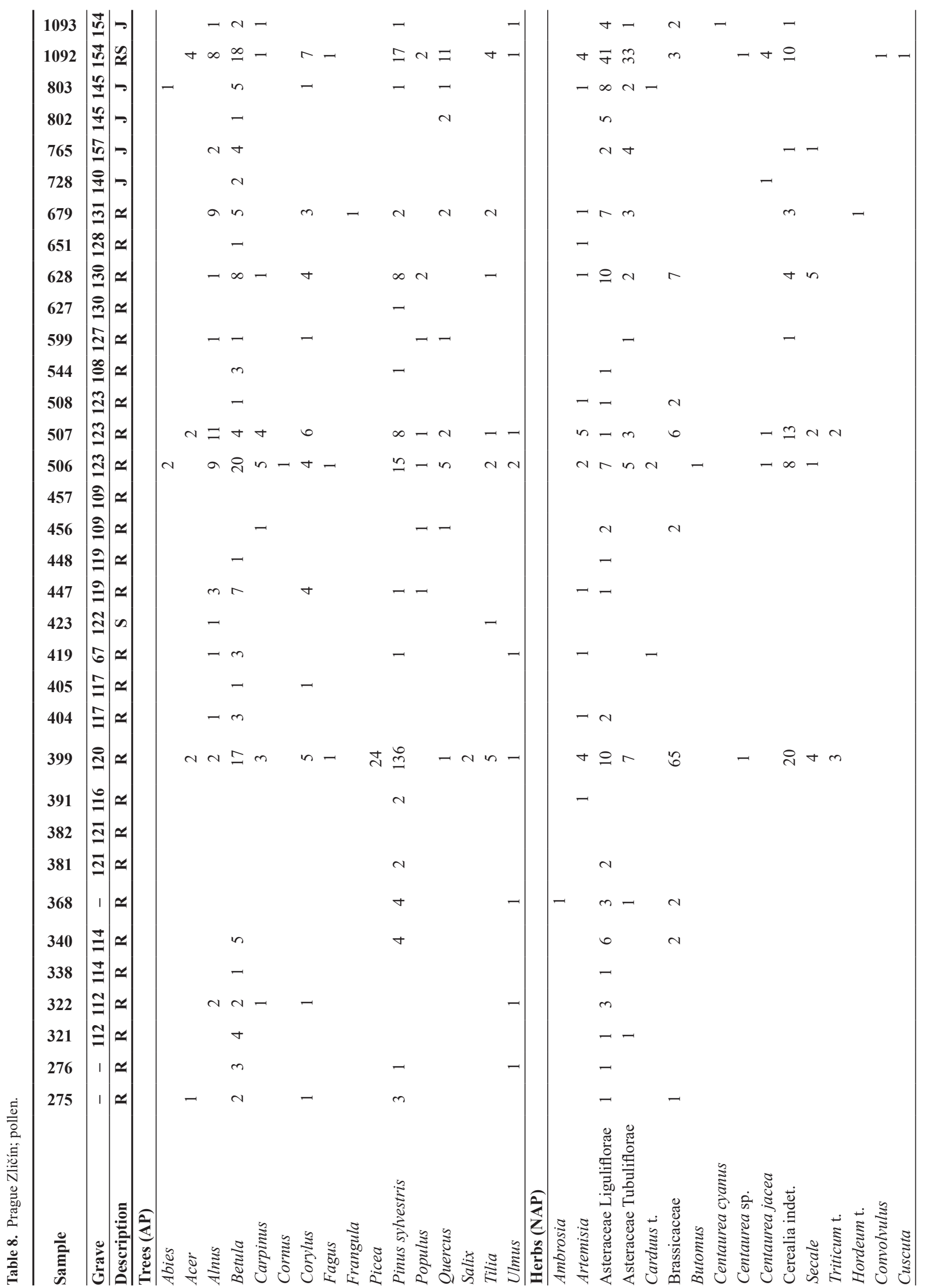




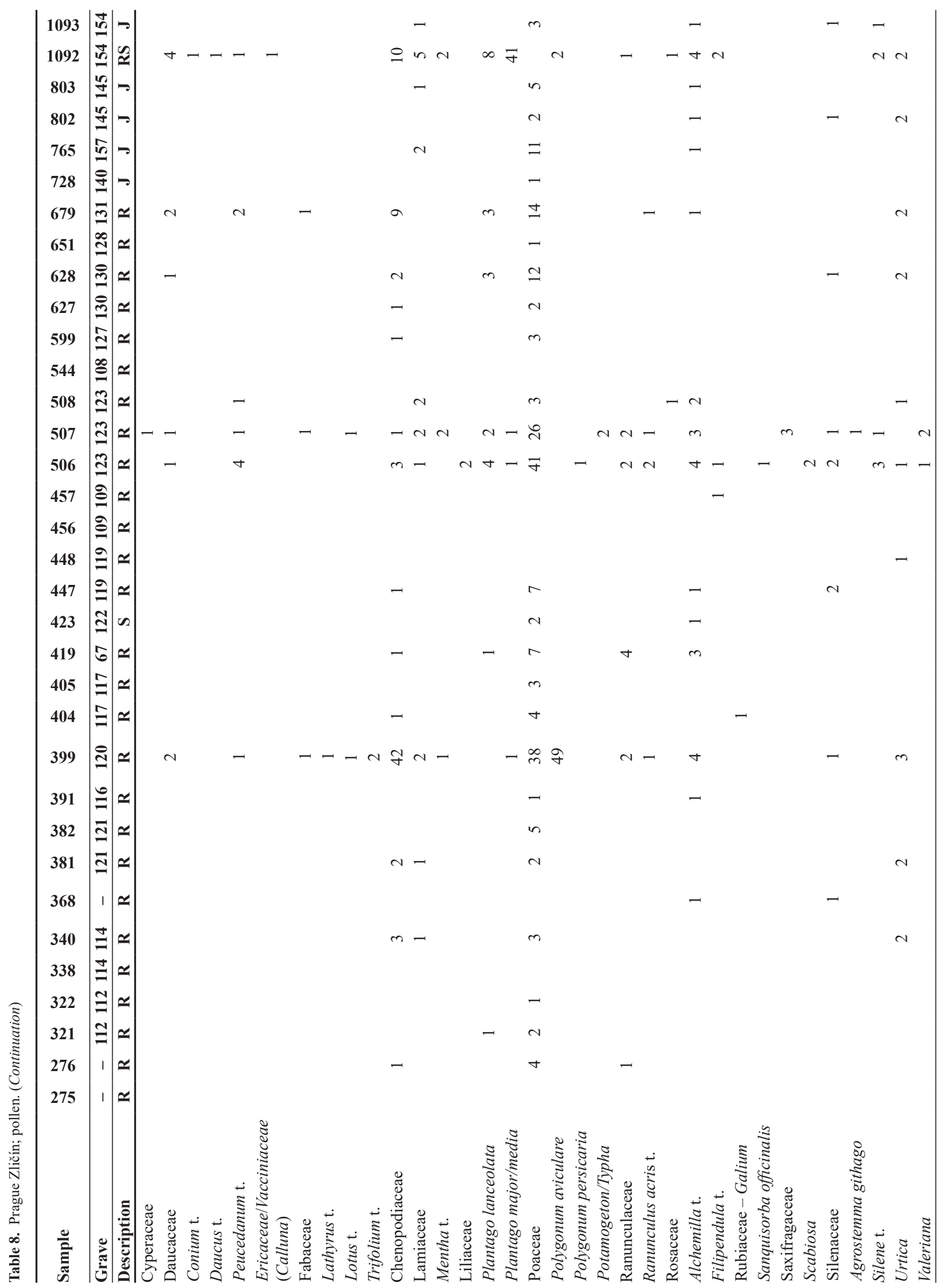




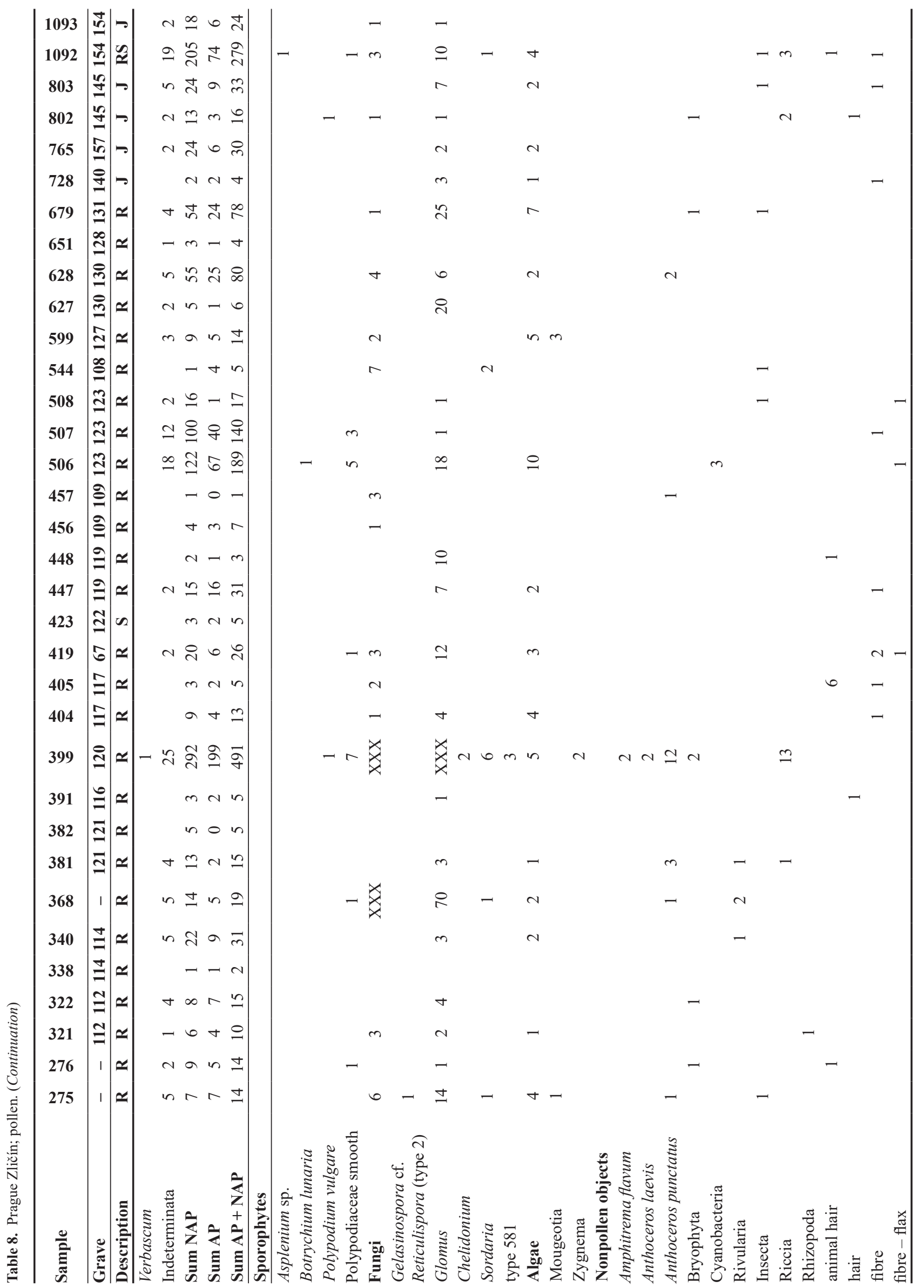




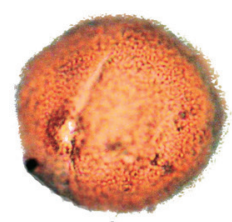

A

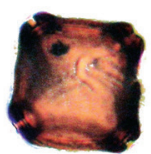

$\mathrm{E}$

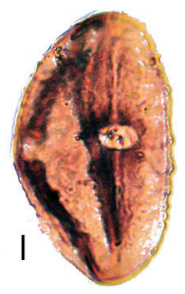

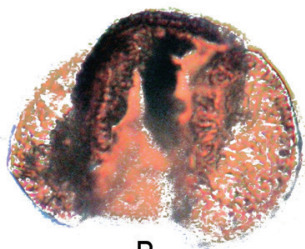

B

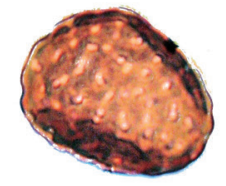

C
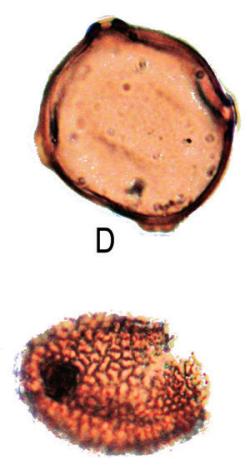

$\mathrm{H}$
Figure 14. Prague Zličín; selected pollen grains. A - Quercus, B - Pinus, C - Chenopidiaceae, D - Carpinus, E - Alnus, F - Trifolium, G - Polygonum aviculare, $\mathrm{H}$ - Brassicacee, I - Lathyrus t., J - Mentha t., $\mathrm{K}$-Anthoceous punctatus, $\mathrm{L}$ - Cerealia indet. by the pelvis); and grave 154 (sample 1092, bottom of the coffin, by the pelvis).

\subsubsection{Grave 120 (sample 399, negative 808, the bottom of the grave).}

Of woody species, the pollen of Pinus sylvestris prevailed. Picea could probably represent a fall from higher altitudes. Corylus and photophilous Betula were present in a larger quantity. The woody species of the oak-lime-hornbeam forest group (Quercus, Tilia, Carpinus, Acer and Fagus) occurred. The woody species from the floodplain forest group were present to a lesser extent (Alnus, Fraxinus, Populus, Salix and Ulmus). The herbal vegetation was varied. The herbs were prevalent among the synanthropic indicators: Brassicaceae, Chenopodiaceae, Polygonum aviculare, Artemisia, Urtica; Plantago major/media can be considered an indicator of trampling. Cereals (Cerealia indet., Secale and Triticum t.) can be ranked among the cultural crops, along with legumes - the pollen type Lathyrus may point to lentils (Lens culinaris - according to Beug (2004). The meadow species (Asteraceae; Tubuliflorae; Liguliflorae, including Centaurea sp.; Daucaceae; Fabaceae, incl. species Lotus and Trifolium; Lamiaceae; Poaceae; Ranunculaceae; Alchemilla; Silenaceae; and Verbascum) were also observed within the spectrum. The others can be ranked among the more hygrophilic types, such as Mentha and Ranunculus acris.

In addition, the spores of undetermined fungi (Fungi indet.), probably some Ascomycetes on bark and wood, were observed. The spores of the genus Glomus, the fungi species living in symbiosis with plant roots, was also determined, as well as coprophilic Sordaria. Also interesting was an occurrence of Chaetomium. It is a dark-walled mould normally found in soil, air, cellulose and plant debris, and can cause an infection in humans (Ellis, Ellis 1985). Algae were present in small amounts. The water algae Zygnema was also caught (Komárek, Jankovská 2001). In addition to the findings of algae and fungi, the spores of bryophytes, the liverwort Riccia, and hornwort Anthoceros punctatus, were found; the latter is an indicator of disturbed soils (Boros, Járai-Komlódi 1975). There was likewise an occurrence of Rhizopoda (Amphitrema flavum) among the non-pollen objects.

\subsubsection{Grave 123, sample 506 (negative 821, the bottom of the coffin/upper part - head area)}

In this sample, the pollen of Betula prevailed among the trees, while Pinus sylvestris was plentifully covered. A second coniferous tree was determined as Abies. The group of oak-lime-hornbeam forest involved Quercus, Carpinus, Tilia, and Fagus. The hydrophilic woody species, such as Alnus, Populus and Ulmus occurred again. Corylus and Cornus were represented among shrubs. There was more pollen from herbs than from trees. The meadow species predominated: Asteraceae; Tubuliflorae; and Liguliflorae, incl. Centaurea jacea; Daucaceae, incl. Peucedanum t., Lamiaceae; Liliaceae, Plantago lanceolata; Poaceae; Ranunculaceae, incl. Ranunculus acris t.; Alchemilla; Filipendula; Scabiosa; Sanquisorba officinalis; and Valeriana. Carduus, Brassicaceae, Chenopodiaceae, Artemisia, Silenaceae, Urtica can be ranked among the synanthropic taxa. Polygonum persicaria and Butomus may grow in the wetter places. Butomus can be used as a food source because of its starch content. Cereals (Cerealia indet. Secale) were determined among the cultural crops. The spores of the group Polypodiaceae, as well as Botrychium lunaria, occurred. The sample contained non-pollen objects, such as undetermined algae, fungi, Cyanobacteria and some fibre (probably flax). 


\subsubsection{Grave 123, sample 507 (negative 821, the bottom of coffin/middle part)}

The second sample from this grave was similar to the previous sample. The floodplain woody species (Alnus, Ulmus and Populus) prevailed among the woody plants, the woody species of the oak-lime-hornbeam forest group were present to a lesser extent (Quercus, Tilia, Carpinus, and Acer). Pinus sylvestris, Corylus and Betula were present in larger amounts.

The herbs prevailed over woody species. The meadow species - Asteraceae; Tubuliflorae and Liguliflorae, incl. Centaurea jacea; Daucaceae, Fabaceae, incl. Lotus; Lamiaceae, Plantago lanceolata; Poaceae; Ranunculaceae; Alchemilla predominated among the herbs. Other synanthropic plants: Artemisia; Brassicaceae; Chenopodiaceae; Silenaceae; and the weed corn-cockle (Agrostemma githago) were confirmed. The sample contained the pollen of cereals; individual types were determined as wheat (Triticum t.) and rye (Secale), as well as further undetermined cereals (Cerealia indet.). The pollen grains were corroded. Other herbs might have overgrown the wetter positions, e.g. Mentha, Valeriana, Ranunculus acris t. The genera Typha might have grown directly in the water. Rhizomes of common cattail contain starch (Kurzawska et al. 2014). The spores of the group Polypodiaceae, as well as Fungi (Glomus), occurred.

\subsubsection{Grave 154, sample 1092 (context 1573, the fill of coffin/middle area)}

Sample no. 1092 contained more than one hundred grains. The species Betula and Pinus sylvestris prevailed among the woody plants. The species of the oak-lime-hornbeam forest group were present to a lesser extent (Quercus, Tilia, Carpinus, Acer and Fagus). The floodplain woody species (Alnus, Ulmus and Populus) were also present.

The herbal vegetation was varied. The meadow taxa prevailed among the herbs: Asteraceae; Liguliflorae; Tubuliflorae, incl. Centaurea sp., C. jacea; Daucaceae; Lamiaceae; Poaceae; Plantago lanceolata; Ranunculaceae; Rosaceae, incl. Alchemilla and Filipendula; and Silenaceae. The synanthropic plants Chenopodiaceae, Brassicaceae, Artemisia, Urtica, Convolvulus were determined. The pollen type of cereals (Cerealia indet.) was determined, as was the species Daucus t. used as a cultural crop. The occurrence of heather-Calluna, which can be regarded as an indicator of poor soils frequently degraded by human activity - is quite interesting. Among the non-pollen objects there was an interesting occurrence of coprophilic fungi (Sordaria) together with Fungi indet. and Glomus. Particles (hairs) most likely came from insect and animal bodies.

\section{Discussion}

\subsection{Dating of the graves and their infill}

All available radiocarbon dates (Figure 3; Table 3) based on human bones support the archaeological dating of the burials (Vávra, Kuchařík 2015) to the Migration Period (ca $5^{\text {th }}$ century $\mathrm{AD}$ and the turn of the $5^{\text {th }}$ and $6^{\text {th }}$ century $\mathrm{AD}$ ), the so-called Vinařice group. However, it is clear that not all recovered finds, artefacts, and ecofacts are of this date.

For example, pottery fragments of pre- or protohistoric date, ranging from the Neolithic to La Tène period, were recorded as intrusions in the infill of the graves, due to processes connected with contamination and residuality in the past.

The strong surface erosion of artefacts, high fragmentation level, and overall bad preservation did not allow closer chronological determination in some cases, and indicated exposure to long-term and/or vigorous pre-depositional transformations. The existence of earlier - late Iron Age to Early Roman period - human activities in the area has been indicated by the radiocarbon dating of an animal bone retrieved from the fill of grave 142 (feature 1555, Poz-64646, 1970 \pm 30 BP; after calibration 45 BC-85 AD, $95.4 \%$ ). Possibility that some parts of the plant remains are also of this age cannot be ruled out.

In addition, radiocarbon dating of selected plant remains indicates that part of the plant remains had been contaminated from the much younger "sub-recent to modern" age. For example, the coffee bean (Coffea arabica) dated to modern times (UGAMS 20578) was recovered from the coffin in grave no. 31 (layer 387), the carbonized caryopsis of Hordeum vulgare dated to $75 \mathrm{BP} \pm 30$ (after calibration 1690 1925 AD, 95,4\%; Poz-64640) came from grave no. 175 (sample 1333), and the non-carbonized seed of Ficus carica dated to $210 \mathrm{BP} \pm 25$ (after calibration $1646 \mathrm{AD}$ - recent, $93 \%$; UGAMS 20579) from grave no. 164. It is highly unlikely that all these dates are the result of dating contaminated material. They were pre-treated in $\mathrm{HCl}$ prior to the dating in CAIS. It is more plausible to suggest that: a) the infill of graves consists of a mixture of finds from different periods, attesting to previous and later occupation or use on this site; and, b) despite many preventive arrangements during the excavations-undertaken in unfavourable weather conditionsand during the flotation of the samples, it was not possible to avoid the retrieval of contaminating material (finds dated as recent). The danger of not recognizing the "irrelevant" finds in multi-cultural sites is considerable, especially if many plant taxa were used or occurred on the sites over several millennia. This can lead to unreal values/counts of the taxa within studied contexts, periods, or sites. However, the preservation of some earlier fragile plant macroremains (e.g. Asteraceae, Apiaceae) from the culture layers and features which became, due to the postdepositional processes, part of the secondary looting shaft infill, is not presupposed to a high degree. Moreover, the spectrum of crops from grave samples did not correspond with the crop spectrum of the Neolithic or Late Bronze Age in central Bohemia (Kočár, Dreslerová 2010; Dreslerová, Kočár 2013). It is impossible to wholly exclude contamination by Late Bronze Age crops, but it is possible to suppose the dominance of Triticum dicoccum for the Late Bronze Age with regard to the site's localization in an "old settlement area" in loess bedrock 
and cambisol. The structures of crops (the proportion of the species) in the samples from the Migration Period graves in Zličín are different from the Late Bronze Age crop structures of settlements unearthed in the western outskirts of contemporary Prague (e.g. Kněževes, Kněžívka, Hostivice; see Dreslerová et al. 2013). Therefore, we suppose that part of the collection of carbonized macroremains is possible to date to the Migration Period. Differences between Zličín and Březno (Tempír 2007) could be the result of real differences between both the communities in their settlement strategies and agricultural management, or by the way their burial rites and rituals are connected with their crops.

Conversely, contamination by later/recent plant macroremains was confirmed, for example by noncarbonized remains of Amaranthus sp. that were in samples from graves, nonfuneral features and roads. Most of the species of Amaranthus are neophytes (Kubát et al. 2002) and their presence before the $16^{\text {th }}$ century $\mathrm{AD}$ is improbable.

Seeds of Amaranthus sp. are very small and could easily penetrate the soil profile. Helianthus sp. and also Pistacia vera are probably connected with recent contamination by workers during the excavation or flotation. Diasporas of Coffea cf. arabica, Ficus carica and Prunus persica were degraded in their surfaces and did not look recent (Figure 9). However, the peach stone was considered a Migration Period grave provision because of the large size of the find and the reality that the stones were found during the excavation, not in flotation ( $c f$. Quast, Siegmann 2000). Imports of luxury food (including pistachio, figs and peaches) to central Europe during the Roman Period were well documented, so the dating of finds in Prague Zličín were problematic without the radiocarbon dating of individual remains (Bekels, Jacomet 2003; Van der Veen 2011). Plant macroremains from Prague Zličín probably consist of three main groups: 1) residuals of plant material from earlier occupation events; 2) plant remains from the Migration Period; and, 3) later contaminations - from any time after the burial up to recent times.

\subsection{Formation of the fill of the graves}

Archaeologists usually tend to consider a burial as a result of a single event and, therefore, the grave content is ordinarily described as "a discrete unit of finds". For the jewellery and other direct burial provisions (grave goods), this is probably the case. However, the data obtained here show a much more complicated picture; one which has methodological potential, at least. The mere presence of looting shafts (i.e. secondary interventions) should act as a great warning for the researcher when considering the mechanisms of grave fill formation. The structure of the macroremains and pollen grains reflects a long-term "dumping ground", turning every single grave into an "environmental trap" exposed for a long time to numerous external influences. The botanical remains can be, in principle, divided into three sub-assemblages related to different times. Residuals represent the ante quem finds predating the burials, therefore we describe this group as an intrusion transformed and transported from the original (at the site unrecognized) cultural layers. The second group is ad quem related to the grave itself. The contamination set of the botanical remains is younger then the burials and emerged post quem. It seems that seeds of plants were not used as grave offerings during the Migration Period. This can be postulated because the density of both carbonized and non-carbonized remains in the bottom parts of the graves is the same or lower as elsewhere in the graves (Figure 4).

Carbonized macroremains which predate (ante quem) the burials are most probably connected to various settlement activities of people living in the area in pre- or protohistory. The recovered taxa and types of remains indicate that they could be the result of, for example, non/intentional burning of grasslands or ruderal areas, or household ovens, and/or specialised kilns necessary for iron production (presupposed
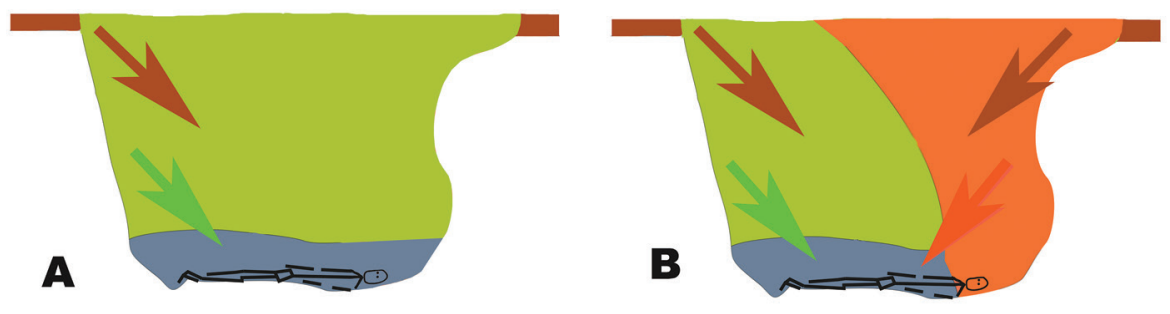

Figure 15. Prague Zličín; model of infiltration of plant remains into the contexts of graves (blue - coffins, green - graves infill, orange - looting shafts, purple topsoil, brown - cultural layer.
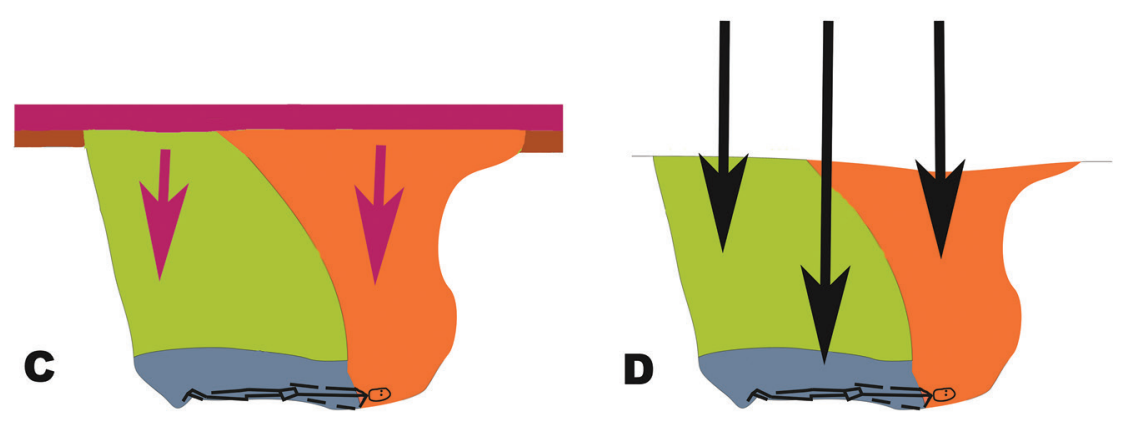
in the western outskirts of Prague for the Roman/Migration Periods).

The following hypothetical reconstruction of processes connected with the development of the site from the time of funeral activity to the time of archaeological excavation is based on archaeobotanical data - taxa structure and taxa density within samples. First, grave pits were dug in areas where the topsoil (and layers below) represented a cultural layer with plant macro and micro remains. Unfortunately, the topsoil with the cultural layer was removed by a construction company prior to the excavations, so the comparative data were not available. Second, the coffin with the deceased (and associated grave goods) was lowered down into the grave-pit. Third, the pit was re-filled. This accounts for the presence of "older" charred plant macroremains, and the mixing of earlier and-with the burial-contemporary plant material (Figure 15A).

After some time, a looting shaft was dug and the grave was robbed $^{1}$. The looting shaft was not filled immediately, but was left open and it filled up gradually, such that plant material from the surface and the nearby cultural layer eroded into the shaft and penetrated to the bottom of the grave. Gradually, the looting shaft was filled in (Figure $15 \mathrm{~B}$ ). The concentration of both carbonized and non-carbonized plant remains in the samples which came from the border between coffins and looting shafts (and looting shaft and grave infill) was higher than in the coffins, shafts and infill (Figure 4). Many taxa were characteristic of samples from the boundary between coffins and looting shafts (Figure 11), so the penetration of plant material after the robbery was probably massive. Therefore, it seems that a majority of the plant material is connected with processes which took place immediately after the robbery. The time between the burial and robbery is not known. But, most probably, the graves were marked, or the robbers knew or could still see the graves, as the looting shafts led to the heads and thoraxes of the deceased. Fragments of wood from coniferous taxa could represent the remains of construction or grave equipment (Doležal, Vávra 2015, 131-149). Wood of Pinus, Picea and Abies was found in all parts of the graves (Figures 13 and 10).

Carbonized remains of crops indicate that something happened between the time of burial of the deceased and the filling of the looting shaft. Firstly, there is a change in the ratio of cereals to pulses (Figure 6), and secondly, while Triticum spelta and T. dicoccum are present in samples from the grave infill, Panicum miliaceum occurs only in contexts connected with the shafts (Figure 8). It seems that part of the material in the shafts (millet, some pulses) either became part of a new cultural layer, or these remains represent the residue of an activity which took place during the reopening of the graves (feasts, rituals, etc.).

\footnotetext{
${ }^{1}$ The interval between the burial and the looting differs from case to case. One must realize that the burial ground was used for some 3-4 generations Proof of the presence of connective tissue was observed in several cases, i.e. there was no decay at the time of reopening (Vávra et al. 2012, pp. 12-13) In some other cases, by contrast, only the skeletons or disturbed assemblage of bones in a variable state of preservation from the original burial were observed.
}

The cultural layer overlying the graves was then transformed again after the looting shafts became filled in. Some transport of much younger seeds through sediments from the surface down to the bottom of the graves (Figure 15 C) is attested by the radiocarbon data (Table 9, Figure 3). Such post quem contamination, e.g. uncharred seeds of Coffea arabica and Ficus carica, was interpreted as being dated to historical and modern periods (history of Coffea in postmedieval contexts; see, for example, Beneš et al. 2014). Waste from Prague was transported to the fields behind the city walls and used as manure from the High Middle Ages onward (Hoffmann 1992, 331-332). Seeds and fruits, present in this waste, could penetrate the soil profile, for example, as a consequence of bioturbation (Karlík, Poschold 2014).

As mentioned above, prior to excavation the topsoil had been removed, to approximately $50 \mathrm{~cm}$ in depth. The excavation of each grave took many days, so the possibility of contamination of sediments by diaspores from the vicinity (e.g. uncharred seeds of Amaranthus sp. and Chenopodium album abundant in the grave fill and looting shafts) or by trampling from the boots of the excavators cannot be ruled out (Figure 15 D). The high number of finds we consider recent contamination (Table 4) is striking, and we cannot be sure if it is not the result of sampling contaminated sediments due to the negligence of the support staff, and/or inconsistencies during the flotation of the samples.

In contrast to plant macroremains, we believe that pollen from the graves in Prague Zličín, taken from the bottom of the graves (below coffins) or from inside the coffins, might better reflect the original content (e.g. Šálková et al. 2015). It is known that the pollen grains of crops attach to the clothing during agricultural work and the processing of crops. Prehistoric textiles usually contain large amounts of cereal pollen (Enevold 2013). Therefore relatively high numbers of cereal pollen and the pollen of meadow plants in the graves at Prague-Zličín could indicate that people were buried in the clothes they used for everyday activity. Spores of fungi which grow on decaying organic matter (like the coprophilic Sordaria) are most probably the direct result of the decay of the coffin and the body of the deceased. Other spores might indicate the presence of flowers (Glomus the most common species growing in symbioses with the roots of flowers), or the lining of the coffin with hay (e.g. Chaetomium).

Various threads of both plant and animal origin were recovered from the flotation samples. We did not succeed in precise identification, but some of them are probably fibres from flax (e.g. Kvavadze, Narimashvili 2006; Kvavadze, Gagoshidze 2008) and some of animal hair. Thread from sample 391 (grave 116) is very similar to human hair.

It could be concluded that both macroremains and pollen analyses did not distinctly reflect the processes connected with the burial rite. Most of the uncharred wood remains, preserved due to the higher soil moisture content, originated from coffins, but some are probably remains from other artefacts buried in the graves: other constructions, tools for digging, offerings. Their relatively high numbers and wide spectra point to their abundance in graves. 


\subsection{Problems with the reflection of the environment}

Pollen spectra obtained from grave infill in the Prague Zličín burial ground could be considered protohistorical, because most of the positive pollen samples were taken from cleaned profiles of the bottoms of the graves. These pollen grains could have several origins: flowers in the coffin; pollen penetrated into the clothing or funeral textiles; pollen rain at the time of the burial process; contamination of the infill of the coffin after the robbing of the grave through the looting shaft; or, contamination by the processes of bioturbation.

No sample from contexts different from the coffin area was representative. It is possible to suppose that samples from various contexts could be positive in the case of contamination of pollen samples. On the other hand, four representative pollen samples from the bottoms of graves could be, with caution, interpreted as a reflection of the environment of the Migration Period based on the following consideration. Pollen samples are generally partly compatible with the macroremains and wood samples from coffins (R). But, in detail, direct comparison could only be applied in the case of grave 154 (where the spectrum of the macroremains does not contains any neophytes), because samples of macroremains from graves 120 and 124 are unfortunately not available. The significant structure of wood/charcoals with dominant Pinus sylvestris corresponds with the pollen structure in grave 154 . Pollen grains of Quercus as well as charcoals are numerous there. Despite the fact the pollen of Picea was not present, its wood was numerous. It could reflect the coffin or grave construction. Both pollen and macroremains from grave 154 reflected dominant ruderal vegetation.

The general picture of the vegetation reconstruction gained by different methods from a number of the graves, however, does not reflect only the Migration Period (part of the plant macroremains is certainly later-contamination/perhapsearlier-residuals). Rather, it widely shows the development of the cultural landscape of the central Bohemian region at a time of human activity in protohistory, potentially at the time of the contamination of the grave infill.

If the fill was actually significantly contaminated by earlier plant material, the contamination would have occurred at a time when field or rubble dominated the site. A responsible reconstruction of the environment of the area in the hinterland of the burial ground would need to obtain comparative material from settlement features. But settlement features of the Migration Period in Prague Zličín have not been found; in Bohemia they have been found infrequently and have had a low density of macroremains.

The samples from the sandy sediments contained rather a small amount of corroded palynomorphs, or they were quite sterile (the rest of samples). This has probably been caused by oxidation and mechanical processes during sedimentation, which causes a loss of pollen from the sedimentary record (Havinga 1967). This does not concern four samples that, on the contrary, were abounding in pollen, but also contained corroded palynomorphs.

The pollen assemblages from the sediment samples very clearly reflected the surrounding local vegetation at the time of pollen sedimentation. The ratio of woody species and herbs in individual samples apparently reflects the human presence and influence on the surroundings. The landscape was probably sparsely covered with trees. The woody species of the oaklime-hornbeam forest group were documented. The occurrence of hygrophilous woody species and trees reconstructed the presence of a wetland or spring area in the vicinity. Also, species of wetter habitats appeared. Conifers are represented by Pinus sylvestris, Picea and Abies pollen. The pollen of meadow species prevailed among the herbs. The weed and synanthropic species, as well as cultural crops, also occurred.

The structure of macroremains was well compatible with the pollen structure, but it reflected the local character of the area of the burial ground. The carbonized remains reflected the human activities connected with working with crops and fire. The remains of crops, weeds and ruderal plants were dominant among the carbonized macroremains, while remains of plants typical for different types of meadows, pastures and forests were documented less frequently. Non-carbonized remains probably reflected a natural environment which was deforested, with only occasional occurrences of trees and shrubs (Betula pendula, Tilia sp., Sambucus nigra and S. racemosa). The noncarbonized plant macroremains reconstructed the dominance of ruderal and weedy vegetation in the vicinity of the archaeological site. Also, macroremains of plant species characteristic of the vegetation of trampled habitats were frequent. The species typical for mesophilous meadows and pastures were commonly documented. The rare presence of a Potamogeton macrofossil highlights the presence of water habitat. The presence of Abies alba, Picea abies, Pinus sylvestris needles could draw our attention to the processing of wood.

The result of the anthracological analysis reveals the common composition of the firewood obtained from the vicinity of the site during an unknown time period. The size of many charcoal pieces was very small $(2-3 \mathrm{~mm})$; this is probably connected to some re-deposition of the material. The species spectrum corresponds with the average charcoal rain on prehistoric as well as medieval archaeological sites in the region (Novák et al. 2012). The composition of the charcoal species is characteristic of the dominance of oak and pine. Dating of the charcoal collection was problematic without the radiocarbon dating of every individual piece of charcoal. Results of the anthracological analysis indicate the presence of acidophilous oak forest (as. Luzulo-Quercetum). The high proportion of Pinus and Quercus, and the rare occurrences of other trees, probably suggest an open and low woodland canopy. The low species diversity may indicate the important human impact on the environment in the area surrounding the archaeological site. As potential natural vegetation, the acidophilous oak forest (Luzulo-Quercetum) and oak-hornbeam forest (Melampyro-Carpinetum) has been hereby assumed (Neuhäuselová 2001). Anthracological analysis generally supposes that people have probably obtained firewood from the woody species growing in the close vicinity of archaeological sites (Shackleton, Prins 1992; Jansen et al. 2013). The firewood is considered to be mostly non-selective, but the charcoal spectra from the wood 
for those special purposes, or wood that was imported from the wider area, generally show reduced species composition (e.g. Novák et al. 2012). The structure of woods and charcoals was different both in terms of which species was most dominantly represented, and in their species spectrum. It is possible that the charcoal and wood remains reflected other processes from different times.

It could be concluded that a reconstruction of the natural environment, based on results from features in a site with a long development of human activity and a low density of plant material, is unrealistic without a wide spectrum of radiocarbon data. We supposed that the pollen samples from the bottoms of graves were not contaminated. Based on this pollen we might thus reconstruct the open agricultural landscape. Plant macroremains and the remains of wood and charcoal do not hinder this reconstruction, but the uncertainties are considerable. It could be concluded that the burial ground was located in the cultural landscape of the previous and following periods, and that the area was intensively exploited by the planting of fields, depositing of waste in rubble sites, etc. Based on the results from the Migration Period graves in Prague Zličín, we can conclude that this type of material (graves in a multi-cultural settlement area with a low density of macroremains) are insufficient for a contemporary reconstruction of the natural landscape at the time of burial.

\section{Conclusion}

Different sources of botanical materials (macroremains, wood, charcoal pieces and pollen) from the various contexts - coffins, looting shafts and infill from the Migration Period graves in Prague Zličín, excavated in 2005-2008 - indicate the following:

1. Most of the coffins were probably manufactured from Quercus, while other potential equipment used and constructions found within graves were made from coniferous taxa (Picea, Pinus, and Abies).

2. Charcoal pieces from grave contexts are dominated by Quercus and Pinus, while less common is the presence of Fagus silvatica. Charcoal pieces of Abies, Acer, Betula, Corylus, Picea, Salix/Populus, and Tilia are not numerous. Charcoal pieces from the graves most probably reflect the wood taxa used for fuel in the area of the burial ground and are probably connected with secondary re-deposition and a species spectrum corresponding to the average charcoal rain of an archaeological site in this region.

3. The assortment of crops differs from that which has been known for the Migration Period in the Czech Republic. It is more similar to the Roman Period in the Czech Lands (Kočár, Dreslerová 2010) or in the Middle Danube Region (Hajnalová 2011); however, see point 4. For regions that were trading and in contact with Bohemia, the structure of crops is different (e.g. Gorbanenko 2014; Hopf 1979; Rösch, Jacomet, Karg 1992).
4. Plant macroremains recovered from graves seem to be of other than funerary origin. They do not represent grave goods (offerings), but instead originate from farming and household activities performed at the site, or in its close vicinity before and/or after establishment of the graveyard.

5. Despite the fact that the graves were well sampled, it was not possible to reconstruct the burial rite in detail. Sampling methods, though vigorous, were inadequate, as they did not eliminate or take into account the danger of contamination. The density of plant material in the graves was generally low, yet the effect of residuals and contamination was substantial.

\section{Acknowledgement}

This research was supported by the Czech Science Foundation; grant number P405/13-8955S. For support during the completing of this article we wish to thank GAJU 145/2016 H. This article was also supported by inspiring environments of grant Papaver. Centre for human and plant studies in Europe and Northern Africa in the postglacial period, reg. no: cz.1.07/2.3.00/20.0289. We would also like to thank Petr Kočár for his inspirational ideas, and Mária Hajnalová and two anonymous reviewers for their helpful comments. We are also grateful to Michael Hensen for proofreading the text.

\section{References}

ANDERBERG, A. L. 1994: Atlas of seeds and small fruits of NorthwestEuropean plant species with morphological descriptions. Swedish Museum of Natural History, Stockholm.

BEKELS, C., JACOMET, S. 2003: Access to luxury foods in Central Europe during the Roman period: the archaeobotanical evidence. World Archaeology 34/3, 542-557.

BENEŠ, J., ČUlÍKOVÁ, V., KOSŇOVSKÁ, J., FROLÍK, J., MATIÁŠEK, J. 2012: New plants at Prague Castle and Hradčany in the Early Modern Period: a History of selected species. Interdisciplinaria Archaeologica - Natural Sciences in Archaeology III/1/2012, 103-114.

BERGGREN, G. 1981: Atlas of seeds and small fruits of Northwest European plant species with morphological descriptions. Swedish Museum of Natural History, Stockholm.

BEUG, H. J. 2004: Leitfaden der Pollenbestimmung für Mitteleuropa und angrenzende Gebiete. Verlag Dr. Friedrich Pfeil, München.

BOROJEVIC, K. 2011: Interpreting, dating, and reevaluating the botanical assemblage from tell Kedesh: a case study of historical contamination. Journal of Archaeological Science 38, 829-842.

BOROS, Á., JÁRAI-KOMLÓDI, M. 1975: An Atlas of Recent European Moss Spores. Akadémiai Kiadó, Budapest.

BRONK RAMSEY, C. 2013: OxCal 4.2.1. http://c14.arch.ox.ac.uk/oxcal/ OxCal.html.

CAPPERS, R. T. J. et al. 2006-2009: Digital Seed Atlas of the Netherlands. Groningen Institute of Archaeology and the Deutsches Archäologisches Institut, Groningen.

DOLEŽAL, S., VÁVRA, J. 2015: Zločin nebo rituál? In Jiřík et al. 2015: Hroby barbarů v Praze Zličině. Svět živých a mrtvých doby stěhování národiu. Praha.

DRESLEROVÁ, D. - KOČÁR, P. 2013: Trends in cereal cultivation in the Czech Republic from the Neolithic to the Migration period (5500 B.C.A.D. 580). Vegetation History and Archaeobotany 22, 257-268. 
DRESLEROVÁ, D., KOČÁR, P., CHUMAN, T., ŠEFRNA, L., PONIŠTIAK, Š. 2013: Variety in cereal production in the Late Bronze and Early Iron Ages in relation to environmental conditions. Journal of Archaeological Science 40, 1988-2000.

ELLIS, M. B., ELLIS, J. P. 1985: Microfungi on land plants. An identification handbook. Richmond Publishing.

ENEVOLD, R. 2013: Pollen studies of textile material from an Iron Age grave at Hammerum, Denmark. Journal of Archaeological Science 4, $1838-1844$

ERDTMAN, G. 1957: Pollen and Spore Morphology. Plant Taxonomy. Gymnospermae, Pteridophyta, Bryophyta. Almquist and Wiksell, Stockholm.

ERDTMAN, G., BERLUND, B., PRAGLOVSKI, J. 1961. An Introduction to a Scandinavian Pollen Flora. Almqvist \& Wiksell, Stockholm.

GORBANENKO, S. A. 2014: Novije dannije o zemledeliji černjachovskoj kultury (po paleoetnobotaničeskim materialam). Ranneslavjanskij mir $15,277-285$.

GREGUSS, P. 1972: Xylotomy of the living conifers. Akadémiai Kiadó, Budapest.

HAJNALOVÁ, M. 2011: Bread of Sarmatians on the Danube, or evidence of arable farming at the site of Harta-Gátőrház (Bács-Kiskun Country) in the Roman Period. In: SOMOGYVÁRI, Á. V., SZÉKELY, G. (Eds.): A Barbaricum ösvényein. A 2005-ben Kecskeméten tartott tudományos konferencia elöadásai. Kecskemét, 161-167.

HANSSON, A. M., BERGSTRÖM, L. 2002: Archaeobotany in prehistoric graves - concepts and methods. Journal of Nordic Archaeological Science 13, 43-58.

HAVINGA, A. J. 1967: Palynology nad Pollen preservation. Palaeobotany and Palynology Journal 2, 81-98.

HOPF, M. 1982: Vor- und frühgeschichtliche Kulturpflanzen aus dem Nördlichen Deutschland. Kataloge vor- und frühgeschichtlicher Altertümer, Bd. 22. Mainz.

HOPF, M. 1979: Organischen Resten aus den Römisch-fränkischen Gräberfeld von Kräfeld-Gellep. In: Pirling, R. (Ed.): Das römischfränkischen Gräberfeld von Kräfeld-Gellep 1964-65. Germanischen Denkmäler Völkerwanderungszeit B10, Berlin, 208-215.

JANSEN, D., LUNGERSHAUSEN, U., ROBIN, V., DANNATH, Y., NELLE, O. 2013: Wood charcoal from an inland dune complex at Joldelund (Northern Germany). Information on Holocene vegetation and landscape changes. Quaternary International 289, 24-35.

JIŘíK, J. et al. 2015: Hroby barbarů v Praze Zličiné. Svět živých a mrtvých doby stěhováni národì. Muzeum Hlavního města Prahy, Praha.

KARLÍK, P., POSCHOLD, P. 2014: Soil seed-bank composition reveals the land-use history of calcareous grasslands. Acta Oecologica 58, 22-34.

KOČÁR, P., DRESLEROVÁ, D. 2010: Archeobotanické nálezy pěstovaných rostlin v pravěku České republiky. Archeobotanical finds of cultivated plants in the prehistory of the Czech Republic. Památky archeologické 101, 203-242.

KOMÁREK, J., JANKOVSKÁ, V. 2001: Review of the Green Algal Genus Pediastrum. Implication for Pollenanalytical Research. Gebrüder Borntraeger, Berlin

KUBÁT et al. 2002: Klič ke květeně České republiky, Academia, Praha.

KVAVADZE, E., NARIMASHVILI, G. 2006: The remains of Gossypium, Linum and sheep hairs as textile fibers of cotton, flax and wool in palynological material from Bronze Age burials. Palyno-Bulletin 4, 34-37.

KVAVADZE, E., GAGOSHIDZE, I. 2008: Fibres of silk, cotton and flax in a weaving workshop from the first century AD palace of Dedoplis Gora, Georgia. Vegetation History and Archaeobotany 17, 211-215.

LAU, N., PIETA, K, 2014: Das Grab von Poprad-Matejovce in der Slowakei - Konstruktion, Ausstatung und Wiederöffnung eines frühvölkerwanderungszeitlichen Kammergrabes. In: Abegg-Wigg, A., Lau, N. (Eds.): Kammergräber in Barbaricum - Zu Einflüssen und Übergangsphänomenen von der vorrömischen Eisenzeit bis zur Völkerwanderungszeit. Internationale Tagung, Schleswig, $25^{\text {th }}-27^{\text {th }}$ Novemeber 2010. Neumünster - Hamburg, 343-364.

MOORE, P. D., WEBB, J. A., COLLINSON, M. E. 1991: Pollen analysis. $2^{\text {nd }}$ edition. Blackwell, London.

NEUHÄSELOVÁ, Z. 2001: Mapa potenciální prrirozené vegetace České republiky. Praha.

NOVÁK, J. 2009: Dendrologická analýza fragmentů dřevěných hrobových konstrukcí a uhlíkủ ze sídlištních situací. In: Štefan, I., Krutina, I. Raně středověké sídliště, hromadný hrob a pohřebiště na Budči (poloha
Na Týnici). Ke vztahu archeologie a „událostní historie“. Památky archeologické 100, 202-204.

NOVÁK, J., LISÁ, L., POKORNÝ, P., KUNA, M. 2012: Charcoal analyses as an environmental tool for the study of early medieval sunken houses infills in Roztoky near Prague, Czech republic. Journal of Archaeological Science 39, 808-817.

PEARSALL S. D. M. 1989: Palaeoethnobotany: a handbook of procedures. Academic Press, San Diego.

PELLING, R, CAMPBELL, G, CARRUTHERS, W., HUNTER, K., MARSHALL, P. 2015: Exploring contamination (intrusion and residuality) in the archaeobotanical record: case studies from central and southern England. Vegetation History and Archaeobotany 24, 85-99.

QUAST, D., SIEGMANN, M. 2000: Amulett? - Heilmittel? - Schmuck? Unauffällige Funde aus Oberflacht. Archäologisches Korrespondenzblatt 30, 279-294.

REILlE, M. 1995: Pollen et Spores d'Europe et d'Afrique du nord. Laboratoire de Botanique Historique et Palynologie, Marseille.

REIMER, P. J., BARD, E., BAYLISS, A., BECK, J. W., BLACKWELL, P. G., BRONK RAMSEY, C., BUCK, C. E. , CHENG, H.,EDWARDS, R. L., FRIEDRICH, M. , GROOTES, P. M. , GUILDERSON, T. P., HAJDAS, I. , HATTE, C., HEATON, T. J., HOFFMANNM, D.I., HOGG, A. G. , HUGHEN, K. A., KAISER, K. F. , KROMER, B., MANNING, S. W., NIU, M., REIMER, R. W., RICHARDS, D. A., SCOTT, E. M., SOUTHON, J. R., STAFF, R. A., TURNEY, C. S. M., VAN DER PLICHT, J. 2013: INTCAL13 and MARINE13 radiocarbon age calibration curves, $0-50,000$ years cal. BP. Radiocarbon 55, 1869-1887.

RÖSCH, M., JACOMET, S., KARG, S., 1992: The history of cereals in the region of the former Duchy of Swabia (Herzogtum Schwaben) from the Roman to the Post-medieval period: results of archaeobotanical research. Vegetation History and Archaeobotany 1, 193-231.

ŠÁLKOVÁ, T., BEZDĚK, A., BŘEZINOVÁ, H., FARKAŠOVÁ, K., HOUFKOVÁ, P., CHVOJKA, O., JOHN, J., KONÍK, P., KOVAČIKOVÁ, L., MICHÁlEK, J., NOVÁK, J., PAVELKA, J., ŠULÁKOVÁ, H., BEŠTA, T., MYŠKOVÁ, E., WEITER, L., ZRONEK, P. 2015: Bioarchaeological reconstruction of the funeral rite - case study based on organic material from the Hallstatt Period tumulus at the site Zahrádka (South Bohemia, Czech Republic). Památky archeologické 106, 95-135.

SCHWEINGRUBER F. H. 1990: Microscopic Wood Anatomy; Structural variability of stems and twigs in recent and subfossil woods from Central Europe. Birmensdorf, Eidgenössische Forschungsanstalt WSL.

SHACKLETON, C.M., PRINS, F., 1992: Charcoal analysis and the "principle of least effort"- a conceptual model. Journal of Archaeological Science 19, 631-637.

SVOBODA, B. 1965: Čechy v době stěhování národů. Praha.

TEMPÍR, Z. 2007: Feldfruchte und Unkraut der Volkerwanderungszeit in Březno. In: Pleinerová, I.: Březno und Germanische Siedlungen derJungeren Volkerwanderungszeit in Bohmen. Praha, 97-98.

TER BRAAK, C. J. F., ŠMILAUER P. 2002: CANOCO reference manual and CanoDraw for Windows user's guide: software for canonical community ordination (version 4.5). Microcomputer Power, Ithaca, New York, USA.

THEUNE-GROSSKOPF, B 2010: Mit Leier und Schwert. Das frühmittelalterliche "Sängergrab" von Trossingen. Mit Beiträgen von Britt Nowak-Böck, Christina Peek, Manfred Rösch und Joachim Wahl. Archäologischen Landesmuseum Baden-Württemberg, Likias, Friedberg.

THOMMA, B. P. H. J. 2003: Alternaria spp.: from general saprophyte to specific parasite. Molecular Plant Pathology 4/4, 225-236.

VAN DER VEEN, M. 2011: Consumption, Trade and innovation. Exploring the Botanical Remains from the Roman and Islamic Ports at Quseir alQadim, Egypt. Journal of African Monograph Series 6. Frankfurt am Main.

VAN GEEL, B., APTROOT, A., 2006: Fossil ascomycetes in Quaternary deposits. Nova Hedwigia 82, 313-329.

VÁVRA, J., JIŘÍK, J., VÍŠKOVÁ, M., JAROŠOVÁ, I., KUCHAŘÍK, M., KUBÁLEK, P. 2012: The Migration Period Burial Site in Prague-Zličín, Czech Republic. Zeitschrift für Archäologie des Mittelalters 40, 1-26.

VÁVRA, J., KUCHAŘÍK, M. 2015: Výzkum pohřebišsě v Praze-Zličíně. In: Jiřík, J. et al. 2015: Hroby barbarư v Praze Zličíně. Svět živých a mrtvých doby stěhování národì, Praha.

WALANUS, A., NALEPKA, D. 1999. PolPal. Program for counting pollen grains, diagrams plotting and numerical analysis. Acta Paleobotanica 2, 659-661. 